\title{
Investigating the Change in Middle School Students' Mathematical Modeling Competencies according to Their Reading Comprehension Skills Levels*
}

\section{Ortaokul Öğrencilerinin Okuduğunu Anlama Becerisi Düzeylerine Göre Matematiksel Modelleme Yeterliklerindeki Değişimin İncelenmesi}

\author{
Yasemin ALKAN ${ }^{* *}$
}

Mehmet AYDIN*** (iD)

\begin{abstract}
Received: 07 March 2021
Research Article

Accepted: 08 July 2021

ABSTRACT: In this study, how the learning process designed with mathematical modeling activities affects the mathematical modeling competencies of middle school students who are at different levels in terms of reading comprehension skills. In the study, nested (embedded) pattern was preferred among mixed method research designs. The participants of the study consisted of 26 middle school seventh grade students who were selected using the easily accessible situation sampling method, which is one of the purposeful sampling types. In the research, besides mathematical modeling activities, researcher and student diaries were used to obtain qualitative data on the functioning of the application process. "Modeling Activities Opinion Form" was also used at the end of the application process in order to determine the general views of the study group on the activities. The quantitative data of the study were collected through the "Reading Comprehension Test" and "Mathematical Modeling Competence Test", and the collected data were analyzed using both qualitative and quantitative data analysis methods. At the end of the study, it was determined that the mathematical modeling competencies of the students improved, but this development did not follow a stable course during the application process and the interpretation and validation competencies of the students were low.
\end{abstract}

Keywords: Mathematical modeling competence, reading comprehension skill, mathematical modeling activities.

ÖZ: Bu araştırmada, matematiksel modelleme etkinlikleri ile tasarlanan öğrenme sürecinin, okuduğunu anlama becerisi açısından farklı düzeylerde bulunan ortaokul öğrencilerinin matematiksel modelleme yeterliklerini nasıl etkilediği incelenmiştir. Çalışmada, karma yöntem araştırma desenlerinden iç içe (gömülü) desen tercih edilmiştir. Araştırmanın katılımcıları, amaçlı örnekleme türlerinden olan kolay ulaşılabilir durum örneklemesi yöntemiyle seçilen 26 ortaokul yedinci sınıf öğrencisinden oluşmaktadır. Araştırmada, matematiksel modelleme etkinliklerinin yanı sıra; uygulama sürecinin işleyişine dair nitel veriler elde etmek amacıyla araştırmacı ve öğrenci günlüklerinden yararlanılmıştır. Çalışma grubunun etkinlikler ile ilgili genel görüşlerini belirlemek amacıyla uygulama süreci sonunda ayrıca, "Modelleme Etkinlikleri Görüş Formu" kullanılmıştır. Araştırmanın nicel verileri ise, "Okuduğunu Anlama Becerisi Testi" ve "Matematiksel Modelleme Yeterliği Testi" aracılığı ile toplanmış, toplanan veriler nitel ve nicel veri analizi yöntemleri birlikte kullanılarak analiz edilmiştir. Çalışmanın sonunda, öğrencilerin matematiksel modelleme yeterliklerinin geliştiği ancak bu gelişimin uygulama süreci boyunca istikrarlı bir seyir izlemediği ve öğrencilerin özellikle yorumlama ve doğrulama yeterliklerinin düşük olduğu belirlenmiştir.

Anahtar kelimeler: Matematiksel modelleme yeterliği, okuduğunu anlama becerisi, matematiksel modelleme etkinlikleri.

\footnotetext{
* This study is part of the master thesis entitled "Investigating the Change in Middle School Students' Mathematical Modeling Competencies According to Their Reading Comprehension Skills Levels" by first author conducted in supervisor of second author.

** Corresponding Author: Mathematics Teacher, Silvan Gökçetevek Middle School, Diyarbakır, Turkey, yasemin.alkan0301@gmail.com, https://orcid.org/0000-0001-9176-9218

*** Asst. Prof. Dr., Dicle University, Ziya Gökalp Faculty of Education, Diyarbakır, Turkey, mehmet.aydin@dicle.edu.tr, https://orcid.org/0000-0002-0718-8662
}

\section{Citation Information}

Alkan, Y., \& Aydın, M. (2021). Investigating the change in middle school students' mathematical modeling competencies according to their reading comprehension skills levels. Kuramsal Eğitimbilim Dergisi [Journal of Theoretical Educational Science], 14(4), 605-637. 
Mathematical modeling is the process of analyzing a real-life situation by using mathematical methods (Erbaş et al., 2014). Mathematical modeling, which includes the processes of transforming a real-life problem into a mathematical problem, generating mathematical solutions, and then interpreting these mathematical solutions in a real context (Blum \& Leiß, 2007; Borromeo Ferri, 2006; Lesh \& Doerr, 2003), has an important role in generating solutions from a perspective. Although there are various definitions for Mathematical Modeling in the literature, it is seen that it is considered as a process. According to Borromeo Ferri (2006), who defines mathematical modeling as a six-step process, the first step of this process is a complete and correct understanding of the problem situation by the problem solver. The ability to create models by performing these six steps properly and to analyze or compare the given models is defined as "Modeling Competence" (Blum \& Borromeo Ferri, 2009). Another definition for mathematical modeling competence was made by Kaiser and Maa $\beta$ (2007). According to them, mathematical modeling competence is to complete the mathematical modeling process willingly and purposefully. Studies have shown that mathematical modeling improves students' thinking skills, increases their academic achievement and their level of associating mathematics with daily life, and improves a positive attitude towards mathematics (Brown \& Stillman, 2017; Çiltaş \& Işık, 2012; Doruk, 2010; Kaiser \& Schwarz, 2006; Sandalc1, 2013). Considering the general objectives of our country's Elementary Mathematics Course Teaching Program, it is seen that competencies are aimed to be improved such as students' mathematical literacy, understanding and using mathematical concepts, predicting, mental processing, research making, knowledge generation, self-confident attitude towards mathematical problems, expressing mathematical thoughts, reasoning and relating (Ministry of National Education [MoNE], 2018). These general objectives in the program are among the competencies that can be acquired by students through mathematical modeling (Blum \& Borromeo Ferri, 2009; Hidıroğlu, 2015; Lesh \& Doerr, 2003). In many western countries, curriculum reforms, especially at secondary education level, consider mathematical modeling as an important element in current secondary education mathematics programs that prepare students for further education (Blomhøj, 2009). Modeling is of great importance for the present and future lives of students and is an important part of NCTM (National Council of Teachers of Mathematics) principles and standards for school mathematics. It is important for students to learn how to solve modeling problems (Schukajlow et al., 2015).

The first step in solving a mathematics problem is to understand the problem in question. The success of students in reading comprehension skills forms the basis of their success in other courses (Bloom, 1995; Ural \& Ülper, 2013). Studies have shown that reading comprehension is directly related to science achievement (O'Reilly \& McNamara, 2007) and mathematics achievement (Walker et al., 2008), and directly affects students' achievement in other courses (O'Reilly \& McNamara, 2007; Özçelik, 2011; Uzun, 2010; Vilenius-Tuohimaa et al., 2008). All these results show that students' reading comprehension skills can also affect their mathematical modeling competencies in particular.

When looking at the historical development of the studies on mathematical modeling, it is seen that Pollak (1969) defined mathematical modeling as real-life applications of mathematics. It can be said that the real-life problems that Pollak 
discussed as mathematical applications in this study were addressed as problem solving, modeling and mathematical modeling in the 1980s (Kapur, 1982). Modeling studies, which have increased since this date and express real-life mathematical applications and real-life problems mostly as mathematical modeling (e.g., Blum \& Niss, 1991; Pollak, 1997), have started to be handled in different dimensions in the $21^{\text {st }}$ century. For example, while different mathematical modeling approaches and the modeling definitions of these approaches are dealt with epistemologically in some studies (Kaiser \& Sriraman, 2006), some studies have focused on the steps, components and cognitive features that emerge in the mathematical modeling process, which is a common acceptance of different approaches (e.g., Borromeo Ferri, 2006; Şen-Zeytun, 2013). Researchers, who see mathematical modeling as a competence that should be taught, have carried out studies to determine and develop mathematical modeling competencies (e.g., Kaiser, 2007; Tekin-Dede, 2015). On the other hand, since mathematical modeling activities differ from conventional teaching methods (Lesh \& Doerr, 2003), some studies examine students' views and beliefs about mathematical modeling (Kaiser \& Maßß, 2007), while some studies examine the relationships between students' modeling competencies and grade level and mathematics achievement. (Tekin-Dede, 2017). Some studies have also examined how individuals construct mathematical knowledge through mathematical modeling by evaluating modeling in the teaching dimension (Hitt \& González-Martín, 2015; Lesh \& Carmona, 2003).

On the other hand, there are studies in which, such as mathematical modeling, reading comprehension skill is associated with variables such as mathematical reasoning (Erdem, 2016), mathematics achievement (Özdemir \& Sertsöz, 2006), or mathematical performance (Lerkkanen et al., 2005). However, as stated by Ural and Ülper (2013), there are only limited number of studies focusing on the relationship between mathematical modeling competence and reading comprehension skill.

Albayrak and Çiltaş (2017) determined that $71.1 \%$ of the articles and $53.6 \%$ of the theses were conducted with qualitative approaches and mainly using the case study method in the content analysis of 38 articles published in 24 national journals and 28 theses published in 14 different institutes in Turkey on mathematical model and modeling. In addition, they stated that there are a limited number of experimental studies in Turkey on mathematical model and modeling, which are mostly carried out with undergraduate students, and in these studies, how learning occurs with mathematical modeling is not explained in detail. They emphasize that it is necessary to go beyond the standard research designs used and to use more research designs that have not been used or rarely used until today, rather than at the undergraduate level. Due to the importance of mathematical modeling that enables students to perform a learning process in which they are active and intertwined with daily life, it is understood that the use of mathematical modeling in classroom environments should be widespread and research on mathematical modeling should be diversified. Considering the approaches, methods and samples used in previous studies, the lack of a satisfactory number of studies conducted with secondary school students, especially including qualitative findings, and examining the possible relationships between mathematical modeling competencies and reading comprehension skills during an experimental process, lead the researchers to the current study. In this study, mathematical modeling competencies of middle school seventh grade students who have different levels in 
terms of reading comprehension skills were followed through an experimental process to determine the change or development in these competencies. Therefore, it is thought that the results to be obtained will contribute to the relevant literature and the planning of learning environments to be organized for mathematics teaching.

\section{The Relationship between Mathematical Modeling and Reading Comprehension}

In order to solve a math problem, it is necessary to understand the problem correctly. As stated by Krawitz et al. (2017), in mathematical modeling problems, it is clear that reading comprehension is a necessary condition for deriving a situation model from the text, since a real-world situation is often presented in writing, and reading comprehension plays an important role in understanding and further structuring and simplifying the written information presented about the real-world situation. Schmelzer and Schukajlow (2017) also stated that in order to solve a mathematical modeling problem, a superficial combination of numbers given in the problem is not sufficient, and first of all, an in-depth understanding is needed. Based on these expressions, it can be said that students should be able to understand what they read in order to solve problems. According to Yantır (2011), the skills of individuals who do not have the ability to understand what they read, such as understanding, expressing, generating thought, interpreting, analyzing, criticizing, and communicating, are not sufficiently developed. When students encounter a problem, they sometimes try to solve the problem by using the methods they know by heart without fully understanding the problem (Gökkurt et al., 2015). It is clear that the solutions made in this way will not make enough contribution to the learning and mental development of students. For this reason, it can be said that understanding the problem is a prerequisite for problem solving. Whether or not students understand a problem correctly can be understood from stages such as separating the given and desired items, creating a diagram suitable for the problem, and drawing a shape in the process of solving a mathematical problem (Çiftçi et al., 2018). According to Baykul (1995), in order for students to understand a problem, they should express the problem in their own words after reading the problem and write down what is given and requested in the problem.

These statements, which show that reading comprehension skill has an effect on skills such as comprehension, analysis, and interpretation, show that there is a close relationship between mathematical modeling and reading comprehension skill. In the literature, there are studies in which mathematical modeling is associated with reading comprehension (Krawitz et al., 2017; Plath \& Leiss, 2018; Ural \& Ülper, 2013). However, there are not many studies in which reading comprehension is associated with all the sub-steps of mathematical modeling and this relationship is evaluated by using quantitative and qualitative data together during a teaching process. In this respect, this study seems to be important in terms of revealing the relationship between reading comprehension skills and mathematical modeling skills, which constitute a great basis for the efficient education of students.

In the study, it was aimed to examine the effect of the learning process designed with mathematical modeling activities on the mathematical modeling competencies of the seventh-grade middle school students who have different levels in terms of reading comprehension skills. 
In line with this stated purpose, answers were sought for the following subproblems:

1. What is the relationship between students' reading comprehension skills and their mathematical modeling competencies?

2. How do students' mathematical modeling competencies change during the application process?

\section{Method}

\section{Research Model}

In this study, embedded mixed design was preferred among one of the mixed method research designs. In embedded mixed design, quantitative or qualitative data are placed in a wider pattern, and these data sources have a supportive role in the whole pattern (Creswell, 2016). The most common example of embedded mixed design is the pattern that emerged when the researcher included qualitative data into the experimental process (Creswell \& Plano Clark, 2018). In this study, an experimental process was carried out using mathematical modeling activities. The qualitative findings obtained by observing the students' mathematical modeling competencies in the process and taking their opinions were supported by quantitative findings. The research was designed in four steps: pre-application, application process, post-application and interpretation of the data. In this way, it aimed to determine the changes in the students' mathematical modeling competencies before, after, and during the application. The research process, which was designed in four steps, is presented in detail under the title of "main application process".

\section{Participants}

The participants of the research consist of 26 middle school seventh grade students studying in a village school in a district of Diyarbakir in the academic year of 2018-2019. The study group in question is the students who took the "Elective Mathematics Applications Course" at the researcher's school. For the study group, the seventh and eighth grade levels of secondary school were found more appropriate in terms of understanding the activities, communication between students, directing students, and ease of implementation. However, it was thought that students studying in the eighth grade would not be able to express their own mental processes fully, skills and opinions during the research process, especially since their preparation process for the Transition Exam to High Schools (TEHS) in the second term was stressful, so it was decided to work with seventh grade students. In addition, it is thought that the contributions to be provided by this application process, which is carried out with modeling activities, will provide benefits to the participant students for the TEHS that they will enter in the next year. The researcher chose class A among the three seventhgrade classes (A, B, and C) because of the factors such as the stable school attendance of the students in this class, their openness to new methods in teaching, and their more positive attitude towards the course. The participants consist of 16 girls and 10 boys. Students are labeled as S1, S2, S3, .. S26 in codes from 1 to 26 . The students in the participant group come from families who live in rural areas, generally earn their living from agriculture and animal husbandry, have a low or middle income, and the highest education level is high school graduates. 


\section{Data Collection Tools}

The Mathematical Modeling Competence Test consists of three mathematical modeling problems prepared by the researcher to be used as the pre modeling competence test (Pre-MMCT) and the post modeling competence test (Post-MMCT). Each of the "Knowledge Contest", "Sleep Time" and "Book Reading" problems in the test was created by examining the problems in the related literature and mathematics applications textbooks and based on the situations that students may encounter in their daily lives. Since the relationship between mathematical modeling competencies and reading comprehension skills was investigated in the study, modeling activities were not developed for a specific subject but by taking into account the objectives of different subjects. In addition, in order to reveal the mathematical modeling competence levels of the students, some sub-questions that could be instructive for the student were created with the given problem. The questions were formed with two researchers working in a similar subject area and the questions were finalized by taking the opinions of two experts. These questions are presented below:

1. Express the problem in your own words.

2. Explain what information you need to solve the problem.

3. Explain mathematically how you will go for the solution of the problem.

4. Take appropriate actions for the solution of the problem.

5. How can you interpret your solution in relation to real life? Explain.

6. How can you be sure that your result is correct? Explain.

In pilot applications, the "Knowledge Contest" problem was applied to 25 students studying at the 7th grade level, the "Sleep Time" problem to 23 students, and the "Reading Book" problem to 24 students. With the pilot study, necessary arrangements were made in the areas that are not understood in subjects such as the implementation period of the activities, the suitability and adequacy of the materials used, the difficulties encountered in the application, and the language-expression of the problems. For example, in the pilot implementation, it was decided to give 50 minutes to each problem, taking into account the students' problem-solving time and student opinions. The problems were finalized in line with the opinions of two field experts.

Reading Comprehension Skills Test is a multiple-choice achievement test consisting of 30 questions developed by Sert (2010) for 6th grade students and used to measure students' reading comprehension skills. Validity and reliability study was conducted on 110 students by the same researcher. In this study, due to the small size of the sample group in which the test was applied, the KR 20 reliability value of the test was found to be .59 as a result of the statistics. This result is at a moderate level for the reliability of the test (Hinton et al., 2004), showing that the test is reasonably reliable in measuring reading comprehension skills. Although this achievement test was developed for 6th grade students, it was also used at the 7th grade by Kaçar (2015). In this study, the purpose of selecting this test to measure students' reading comprehension skills is to consider that it is suitable for the study group students' levels. In addition, this achievement test was presented to the opinion of a teacher who attended the Turkish lesson at the school where the study group was educated, and it was decided that it was suitable for the levels of the study group students and the objectives of the subject that they expected to acquire. 
Mathematical Modeling Activities consists of 7 mathematical modeling activities prepared to be used in the application process of the research. Football League, Bekir's Birthday Party, Mystery of Unit Cubes, Cinema Hall, Electricity Saving and Rainfall activities were prepared by the researcher, and Oil Spill activity was taken among Programme for International Student Assessment (PISA) in 2012 pilot application questions, considering that it is appropriate for the students' level. Each of the activities was presented to the opinion of two experts in the field and two researchers working in the same field, and the activities were finalized in line with the opinions received. In these activities, in order to reveal the mathematical modeling competencies of the students, similar instructions and activity development procedures were used which are also used in Pre-MMCT and Post-MMCT. Football League and Bekir's Birthday Party activities were applied to the students individually and it was observed that the students had difficulties in the activities. Because of this, the Mystery of Unit Cubes, Cinema Hall, Electricity Saving and Oil Spill activities were applied to the students in groups, both in terms of the convenience they provide and to make the activities more enjoyable for the students. The groups were formed with five for two of them and four for four. The last activity, the amount of rainfall activity, was applied to the students individually in order to see the competencies of each of the students in their modeling competencies more clearly.

Below is an example of one of the activities used in the implementation process:

Figure 1

(Sample Activity): Electricity Saving

\section{ELECTRICITY SAVING}

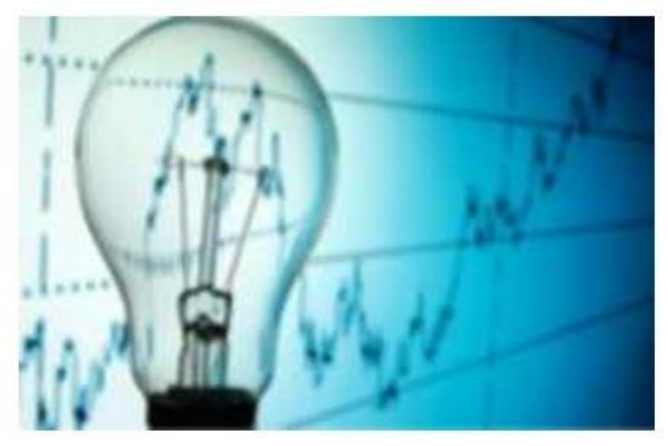

According to statistics, per capita consumption is $3082 \mathrm{kwh}$ of electricity in Turkey in 2017 with 80.81 million population.

According to this, "If each family in the country saves the light of each room in their home for 1 hour, what kind of a reference will be the amount of electricity consumption per individual per year? How can you explain the contribution of this situation to the economy of your country?"

( 1 bulb consumes about 10 watts of energy per hour. $1 \mathrm{kwh}=1000$ watts)

The researcher prepared Modeling Activities Opinion Form to get the study group's general views on mathematical modeling activities at the end of the process. This form consists of 6 open-ended questions such as "Did you have difficulty in doing the activities? Which activity did you have the most difficulty in? Explain with the reasons", "How are these activities different from the math problems you generally encounter? Please, explain", "Do you think there is a relationship between these activities and reading comprehension?". A pool of questions was created using the relevant literature and six questions were selected among these questions that could be adapted to the sub-problems of the research. After the questions were made suitable for the purpose of the research, they were presented to the opinion of two field experts. After the necessary parts were changed, the final form was given to the opinion form. 
The purpose of using the opinion form in this study is to support the findings by determining the general views of the students about the activities. Thus, it is aimed to make the study more comprehensive by obtaining more detailed data about the contributions of the applied activities to students.

The Researcher and Student Diaries were used to record the details of the implementation of each activity throughout the implementation process. The aim of the researcher diaries is to reveal the mathematical modeling competency processes that students could not reveal on their activity papers. For example, it may not always be obvious from the activity sheet whether the student verified, checked the found solution, and corrected it if there is a mistake. It is more appropriate for the researcher to observe the students during the activity and instantly note the places that is considered as important in terms of the reliability of the results. Student diaries, on the other hand, were used to provide data about the student's views and opinions about that activity after each activity.

\section{Data Analysis}

In the research, the maximum score that can be obtained from the reading comprehension test was determined as 30 , and the students' reading comprehension test scores were evaluated by giving 1 point for each correct question. Modeling Competencies Evaluation Rubric was used to score the mathematical modeling competencies of the students. Modeling Competencies Evaluation Rubric was developed by Tekin-Dede and Bukova-Güzel (2014). In the rubric, the mathematical modeling competencies were evaluated in six steps: understanding the problem (UP), simplification (SI), mathematization (MA), working mathematically (WM), interpretation (IN) and verification (VE). In this study, the minimum score for each level was determined as " 0 " and the maximum score as "12". For example, Level 1 corresponds to "0 points", Level 2 to " 4 points", Level 3 to "8 points", and Level 4 to "12 points" in the simplification step evaluated at 4 levels.

In the first sub-problem of the study, Pearson Correlation Coefficient was used to understand whether there is a meaningful relationship between reading comprehension skill and mathematical modeling competence by using simple correlation technique. When analyzing the relationship between the reading comprehension skill and the scores obtained according to each sub-step of mathematical modeling, the "Pearson Correlation Coefficient" was used for the steps in which the scores were normally distributed, and the "Spearman Correlation Coefficient" was used for the steps where the scores were not normally distributed. The qualitative data obtained from student activity papers, diaries and opinion forms were analyzed descriptively with a qualitative approach.

In order to find an answer to the second sub-problem of the study, the modeling competencies of the students in the application process were examined according to their reading comprehension skills and compared by means of column charts. Students' modeling efficacy scores for each activity were determined again through Modeling Competencies Evaluation Rubric. The students were divided into three different levels of reading comprehension using the frequency table created by the researcher using the scores obtained from the reading comprehension test. The frequency table of students' reading comprehension levels is given below: 
Table 1

Frequency Table of Reading Comprehension Levels

\begin{tabular}{ccc}
\hline Reading Comprehension Skill & Score Range & Number of Students \\
\hline Level 1 & $12-17$ & 4 \\
Level 2 & $18-23$ & 16 \\
Level 3 & $24-29$ & 6 \\
\hline
\end{tabular}

While creating the frequency table, firstly, the range of the group was found by taking the difference of the highest score and the lowest score from the test. In order to make it easier to compare with column charts, the number of classes was determined as three, and the class width was found by dividing the range by the number of classes. Score ranges have been established according to the determined class size, and each student is divided into levels according to the received score. The modeling score averages taken from each activity were considered separately for students at each level. In this way, in terms of reading comprehension skills for each activity, the mean scores of mathematical modeling efficacy of level 1, level 2 and level 3 students were determined and compared by means of column charts. In addition, the ideas and thoughts of the students regarding each activity were recorded daily through the student diaries throughout the process, and direct quotations were made from these collected data in some parts of the study. The whole process was observed by the researcher and notes were taken about the important parts. Since it is sometimes not understood from the student papers whether the students have verified the solution that they have obtained and corrected the parts that they found wrong, the taken notes were used to understand whether the students performed the "Verification" step, especially of mathematical modeling. In addition, the taken notes by the researcher were used to understand that in which stages of the activities and why they had difficulties. Proximity to the research area, collecting information directly and in the environment of the event through observations, and the ability to go back to the field to confirm the findings and having opportunity to collect additional information are important features in terms of the validity of qualitative data in a study (Yıldırım \& Şimşek, 2016).

\section{Ethical Procedures}

All procedures performed in this study involving human participants were in accordance with the ethical standards of the institutional research committee. Before the research started, the researcher applied the institutional ethics committee for ethical approval. The ethical committee approval date is November 15, 2018 and the number of the approval document is 111572 .

\section{Main Implementation Process}

The research was carried out in a total of 9 weeks, including the 7-week modeling activities implementation process (MAIP) and the one-week implementation of the pre-test and post-tests. Before the seven-week MAIP, quantitative data on students' modeling competencies and reading comprehension skills were collected through pre-tests. Later, MAIP was started and qualitative data were collected using researcher and student diaries to reveal the students' modeling competencies in detail. 
For quality teaching, it is essential to maintain a permanent balance between (minimum) teacher guidance and (maximum) students' independence (Blum, 2015). For this reason, students were guided at a minimum level during the process, and they were mostly encouraged to act independently. Teacher support was more in the first weeks of the process. In the following weeks, teacher support decreased and student independence increased. After the end of the process, the opinions of the students about the activities were taken through Modeling Activities Opinion Form. Then quantitative data were collected by performing post-tests. The application process of the research is presented in Figure 2:

Figure 2

The Main Implementation Process of the Research

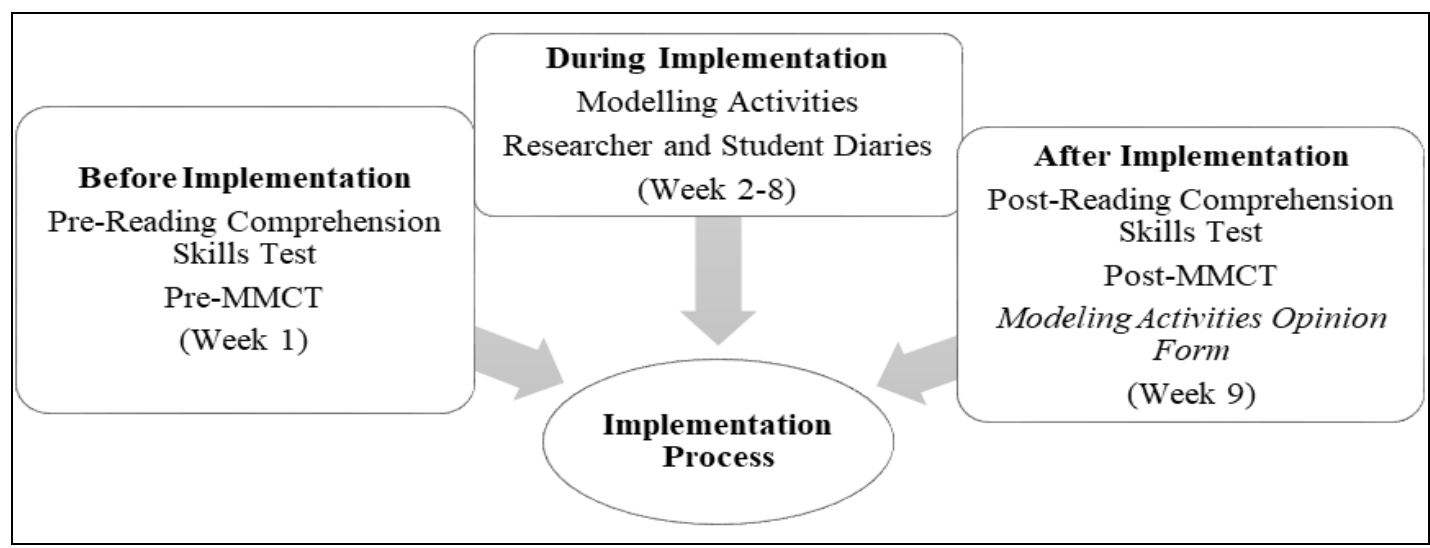

\section{Findings}

Findings on the Relationship between Reading Comprehension Skills and Mathematical Modeling Competence

The relationship between students' mathematical modeling competencies and reading comprehension skills pre-test scores and post-test scores is given in Table 2 together with the sub-steps of mathematical modeling competencies:

Table 2

Pre-test and Post-test Scores for the Relationship between Reading Comprehension Skills and Sub-Steps of Mathematical Modeling Competence

\begin{tabular}{|c|c|c|c|c|c|c|c|}
\hline & & \multicolumn{3}{|c|}{ Pre-test } & \multicolumn{3}{|c|}{ Post-test } \\
\hline & & $N$ & $r$ & $p$ & $N$ & $r$ & $p$ \\
\hline & Mathematical Modeling & 26 & .247 & .223 & 26 & .708 & .000 \\
\hline \multirow{6}{*}{ 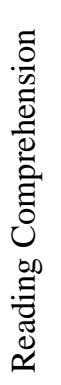 } & Understanding the Problem & 26 & .379 & .057 & 26 & .613 & .001 \\
\hline & Simplification & 26 & .229 & .261 & 26 & .537 & .005 \\
\hline & Mathematicalization & 26 & .182 & .372 & 26 & .592 & .001 \\
\hline & Working mathematically & 26 & .159 & .439 & 26 & .644 & .000 \\
\hline & Interpretation & 26 & .057 & .782 & 26 & .529 & .005 \\
\hline & Verification & 26 & .188 & .358 & 26 & .563 & .003 \\
\hline
\end{tabular}


When Table 2 is examined, it is seen that there is a low level positive relationship between reading comprehension pre-test scores and pre-MMCT scores, $r=.247, p>.01$. However, there is no significant relationship between these two variables. Likewise, when analyzing the results of the analysis on the relationship between the students' pre-test scores in reading comprehension skills and each sub-level of mathematical modeling, it is seen that there is a low-level positive relationship between the students' reading comprehension skill and the scores of each sub-step of mathematical modeling competence. When the post-test scores are examined, it is seen that there is a high level, positive and statistically significant relationship between reading comprehension post-test scores and post-MMCT scores, $r=.708, p<.01$. Accordingly, it can be said that as the reading comprehension skill increases, the level of mathematical modeling competence also increases. Considering the determination coefficient $\left(r^{2}=.50\right)$, it can be said that $50 \%$ of the total variability in mathematical modeling competence is due to reading comprehension. When looking at the relationships between the students' reading comprehension post-test scores and the scores of each sub-level of mathematical modeling competence, it is seen that these relations are moderately, positively and statistically significant. In this case, it can be said that as the students' reading comprehension skills increase, the success levels of each sub-step of mathematical modeling competence also increase.

In the interviews with the students at the end of the implementation process, the students emphasized that in order to solve a mathematical problem or complete a mathematical activity, the problem or activity in question should be understood correctly and completely. The opinions of S20, S8 and S23 students who are at the level 1, 2 and 3 in terms of reading comprehension skills are presented below as an example:

S20: "...The events seem to call us to read a book. Because the more books we read, the easier we can understand and make the questions..."

S20 student, who is at the level 1 in terms of reading comprehension skill, stated that reading a book will make it easier to understand the questions, thus increasing the success in modeling activities. Similarly, S8 stated her opinion as;

S8: “...Yes, it has a relation with reading comprehension. If we didn't understand what we read, we wouldn't know what the problem is asking us. For example, it wants us to explain the problem in our own words in the question. If we cannot understand what we have read, we cannot answer that question...".

According to the S8 student who is at the level 2 in terms of reading comprehension skill, solving a mathematical modeling problem depends on expressing what is desired in the problem. S23 student expressed his opinion as,

S23: "...These activities have something to do with reading comprehension.

Because if we cannot understand what we are reading, we cannot know what the problem requires from us and we cannot solve the problem. In order to be successful in the activities, we must read books frequently so that we can understand the problem when we read the problem...".

S23 student, who was at level 3 in terms of reading comprehension skill, stated that they could not know what is wanted in the problem without understanding what 
they read and emphasized the need to read books in order to understand the problems better.

\section{Development of Mathematical Modeling Competencies in the Process}

The findings obtained in the context of this sub-problem are divided into two parts so that they can be understood more easily by the reader. In the first part, each activity was considered a case. The mathematical modeling competencies of students with different levels of reading comprehension skills during the implementation process were examined in detail with qualitative and quantitative findings. In the second part, each mathematical modeling competence was considered a case, and it was attempted to summarize how the development of mathematical modeling competencies progressed through the seven activities according to the reading comprehension skill levels of the students.

Examining the Development of Modeling Competencies according to Different Reading Comprehension Levels on the Basis of Activity

Findings regarding the First Mathematical Modeling Activity. In the first activity of the study, "Football League", information was given about the points obtained from the matches played in the football league, according to the status of victory, draw and loss. and the students were asked to make possible predictions about the score of their favorite team at the end of the 4th week of the league. As a result, by the end of the 4 th week of the league, they were asked to make possible predictions about the score of their favorite team. The scores of the students, who were divided into three levels according to the scores that they got from the reading comprehension test, from the first modeling activity "Football League" are given in the Figure below according to each sub-step of mathematical modeling:

\section{Figure 3}

Students' Modeling Efficacy Score Averages in the $1^{\text {st }}$ Activity according to Their Reading Comprehension Levels

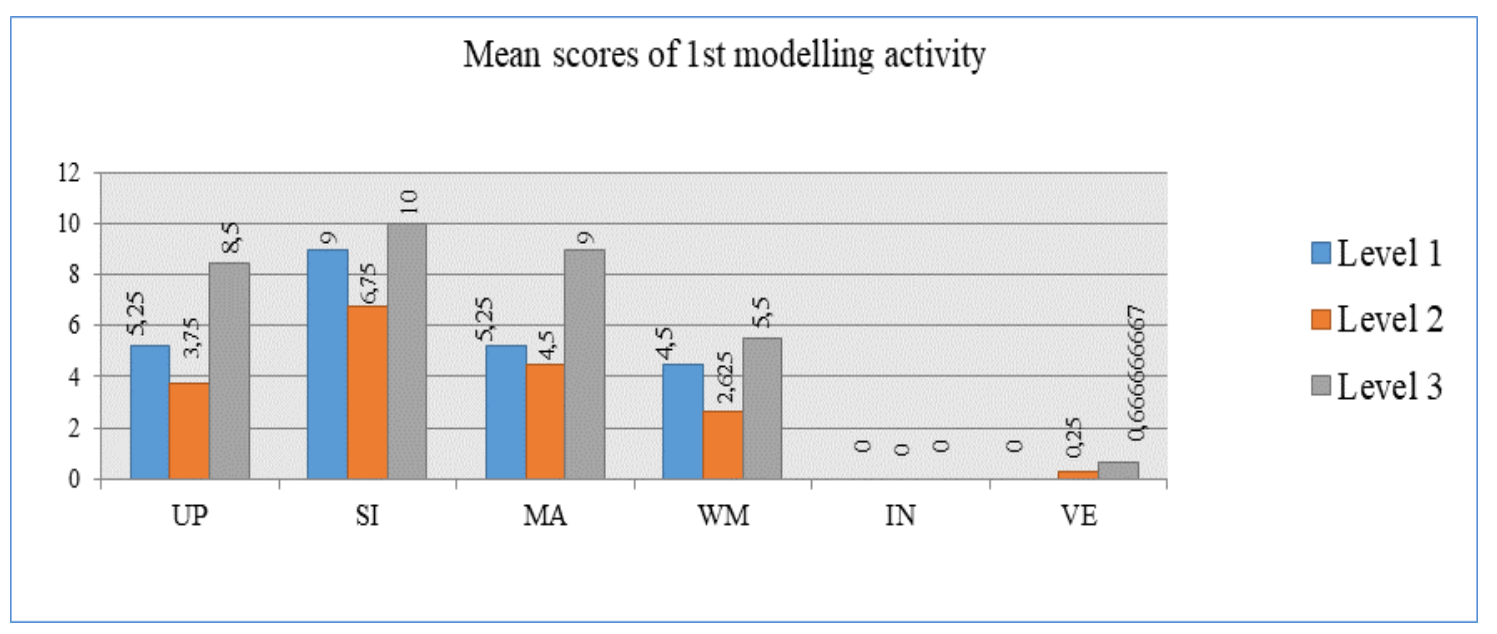

As seen in Figure 3, the students' average scores at the level 3 with the highest reading comprehension skills, according to each step of the mathematical modeling, were higher than the level 1 and level 2 students. The mean scores of mathematical 
modeling efficacy of the students at the level 2 were higher than the level 1 students only in the verification step, and remained behind the level 1 students in the other levels. When the opinions about the activity were examined, it was seen that male students reported more positive opinions than female students. When looking at the Figure, it is seen that the step in which students at all three levels have the highest average is the "simplification" step. However, it is seen that students at all three levels fail in the "interpretation" and "verification" steps. In the opinions taken from the student diaries about this activity, it was seen that the students generally stated that they had difficulty with understanding the activity. Figure 4 shows the activity sheet of the S7 student at level 2 in terms of reading comprehension skill:

Figure 4

Activity Sheet of Student $S 7$

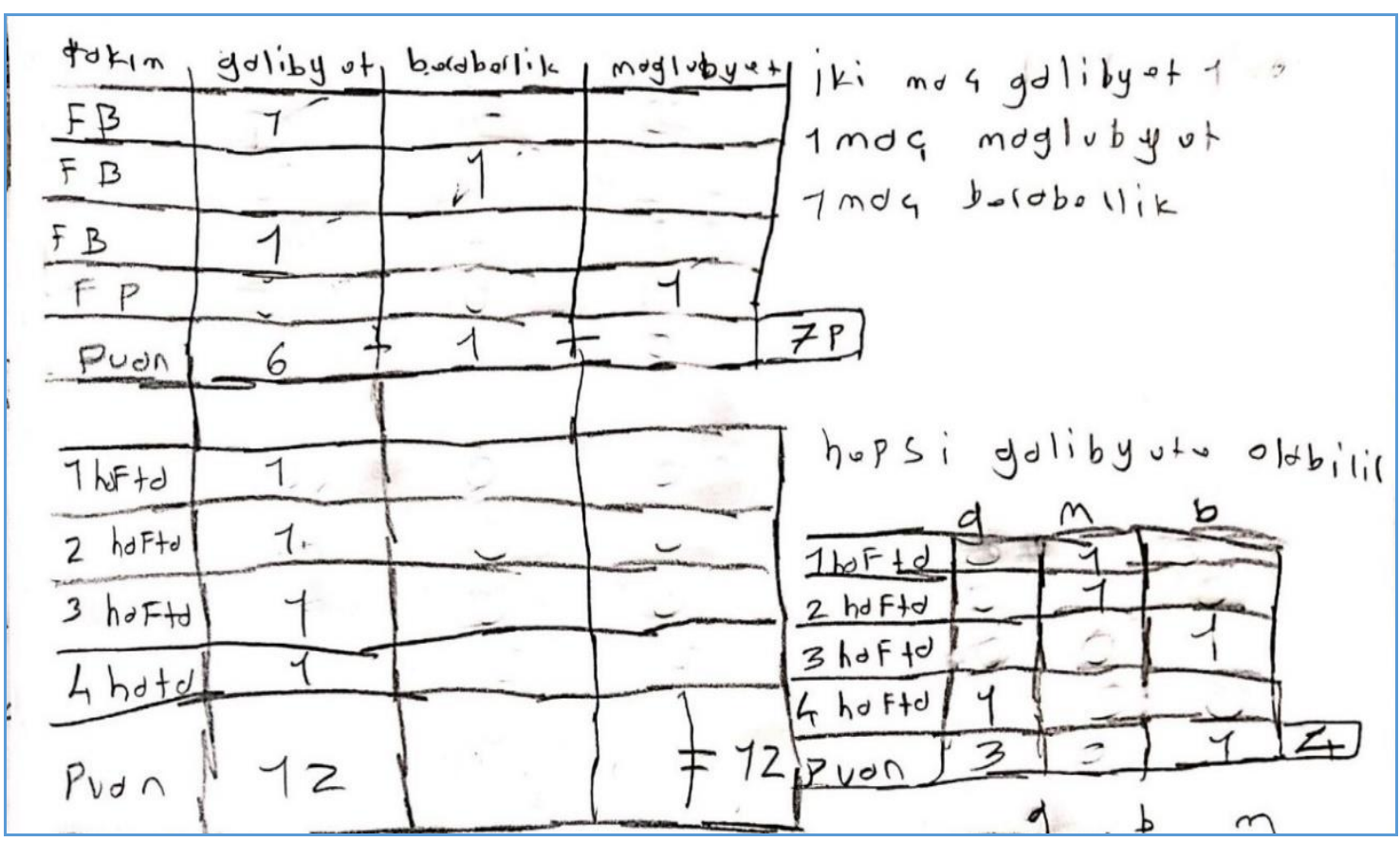

As seen in Figure 4, the student preferred to visualize his solution by drawing a table. The student, who succeeded in understanding the problem, simplifying and mathematical study steps, missed some of the possibilities that could occur and could not complete the solution completely. The student was also unable to comment on the solution and did not check the accuracy of the obtained solution. This situation shows that the student is partially successful in this modeling activity.

Findings regarding the Second Mathematical Modeling Activity. In the second activity of the study, "Bekir's Birthday Party", students were given three price options for a drink order at a birthday party and were asked at least how many drinks they should order in order for the second option to be more convenient than the others. The student scores of this activity, which is also applied individually, are given in the Figure below: 
Figure 5

Students' Modeling Efficiency Score Average in the $2^{\text {nd }}$ Activity according to Their Reading Comprehension Levels

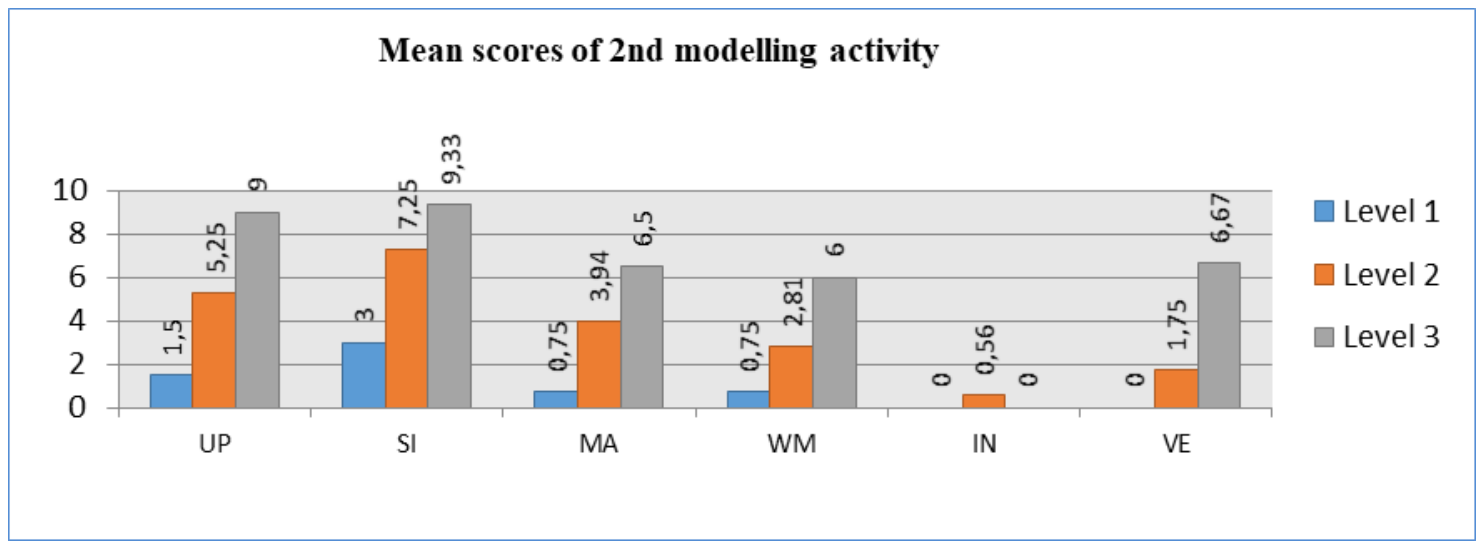

When Figure 5 is examined, it is seen that the students at level 3 are more successful than the students at level 1 and 2, and the level 2 students than the level 1 students in terms of reading comprehension skill. Only in the "interpretation" level, the averages of the students at level 2 seem slightly higher than the others. The reason for this is that only one student at level 2 commented on the found solution. It is seen that the students are weak in the interpretation step in this activity, as in the previous activity. On the other hand, it is seen that there is a significant increase in the averages of level 3 students in the "verification" level. When the averages are examined in general, it is seen that the students at the level 1 and 2 have a higher mean score in the "simplification" level, and the level 3 students in the "understanding the problem" and "simplification" levels compared to the other levels. When the students' opinions about this activity were taken, it was seen that the students expressed more positive opinions in this activity compared to the first activity. Figure 6 shows the activity sheet belonging to student $\mathrm{S} 6$ who is at level 3 in terms of reading comprehension:

Figure 6

Activity sheet of student S6

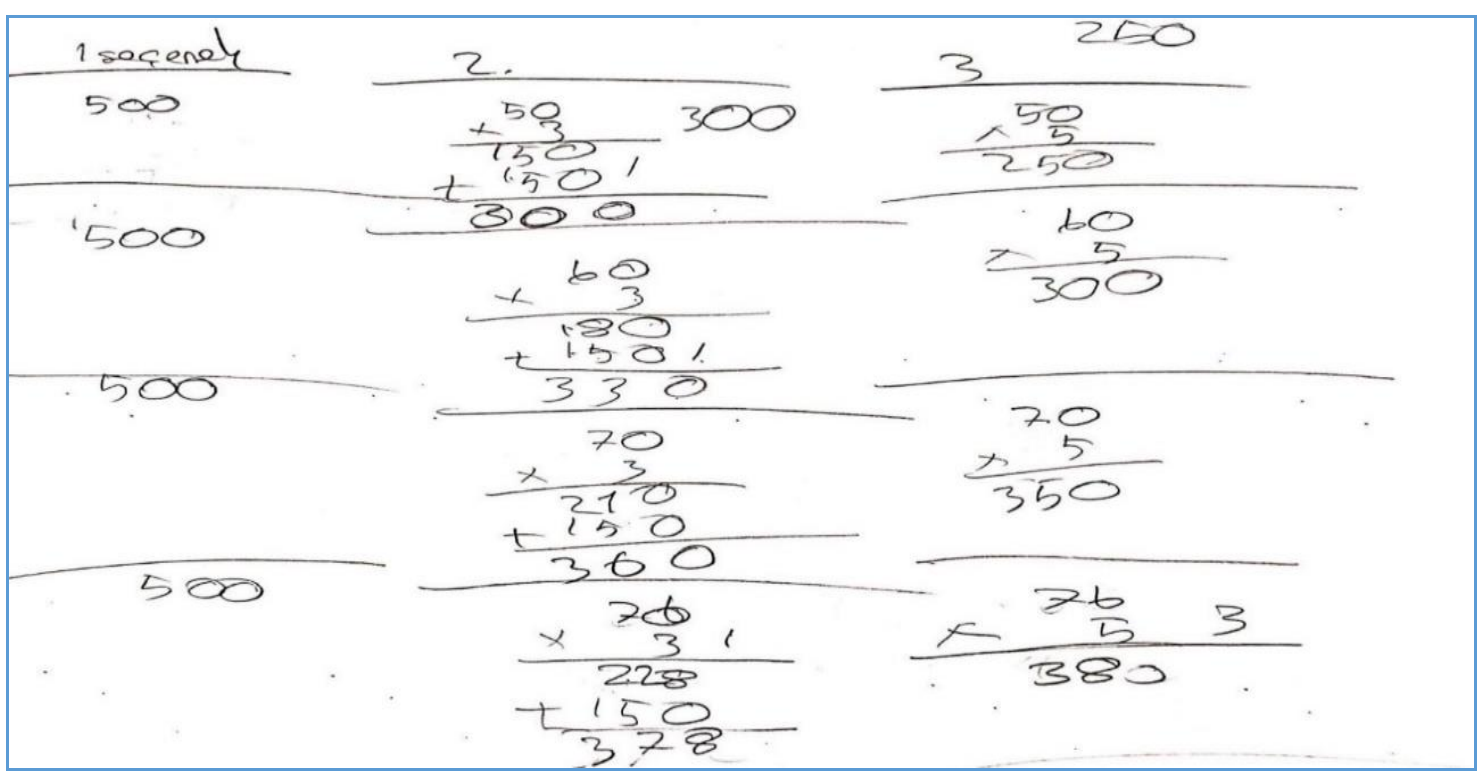


As can be seen in the Figure, the student tried the numbers of 10 by 10 in order to find the number of drinks that would make the $2^{\text {nd }}$ option advantageous, and thus reached the correct answer. It can be said that the student, who developed a way to reach a solution, successfully completed the modeling process up to the mathematical study level. However, the student could not interpret his solution and verify the obtained solution. In this case, it can be said that the student partially completed the modeling process in this activity. In addition, in this activity, it is seen that level 3 students achieved a higher success in the activity compared to other students, and none of the students at the level 1 could not come to the solution stage by creating a suitable model for the solution of the problem.

Findings regarding the Third Mathematical Modeling Activity. In the third activity of the study, "The Mystery of Unit Cubes", students were asked to create completely different rectangular prism models of 48-unit cubes. In order to make the activity fun and to realize permanent learning, the students were divided into groups and 48-unit cubes were given to each group. The data regarding the student scores obtained as a result of evaluating the students' activity papers are shown in the Figure below:

\section{Figure 7}

Students' Modeling Efficiency Score Average in the $3^{\text {rd }}$ Activity according to Their Reading Comprehension Levels

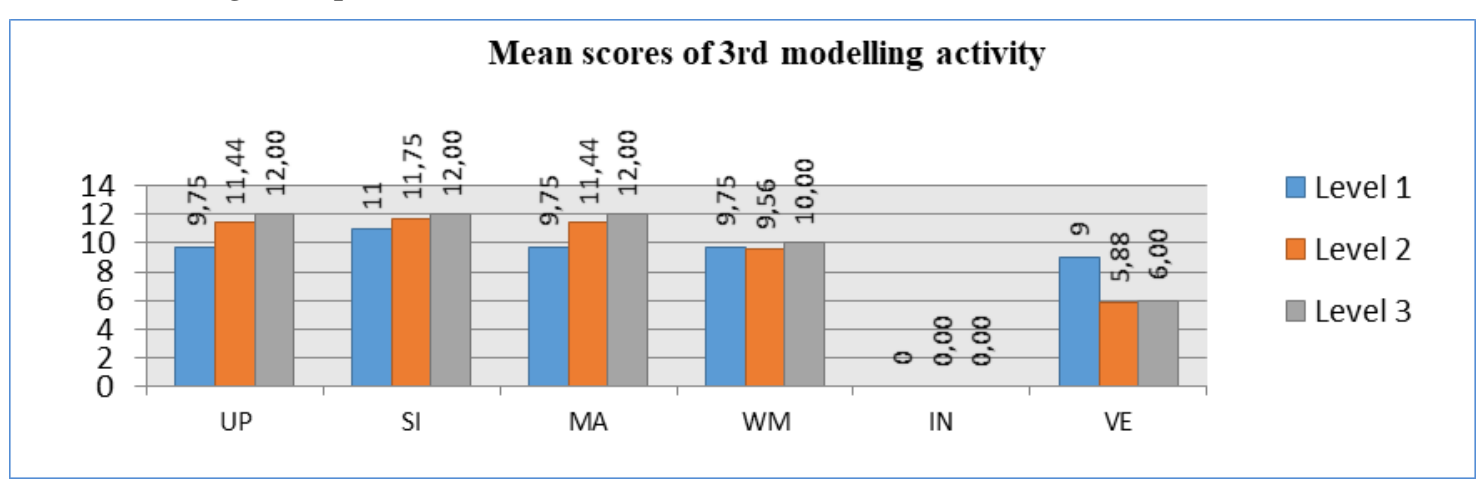

As can be understood from Figure 7, the mean scores of the level 3 students are higher in the first four levels than the other students. In the "verification" step, it is seen that the averages of the level 1 students are higher. In addition, it is seen that the students failed in the "interpretation" stage in this activity. In addition, it is seen that the students are generally successful in other steps except for the "interpretation" step. When the students' opinions about the activity were received, almost all of them stated that they liked the activity. The reason was explained by using concrete materials and working in groups. Figure 8 shows the activity sheet belonging to the student S20 at level 1 in terms of reading comprehension: 
Figure 8

Activity Sheet of S20 Student

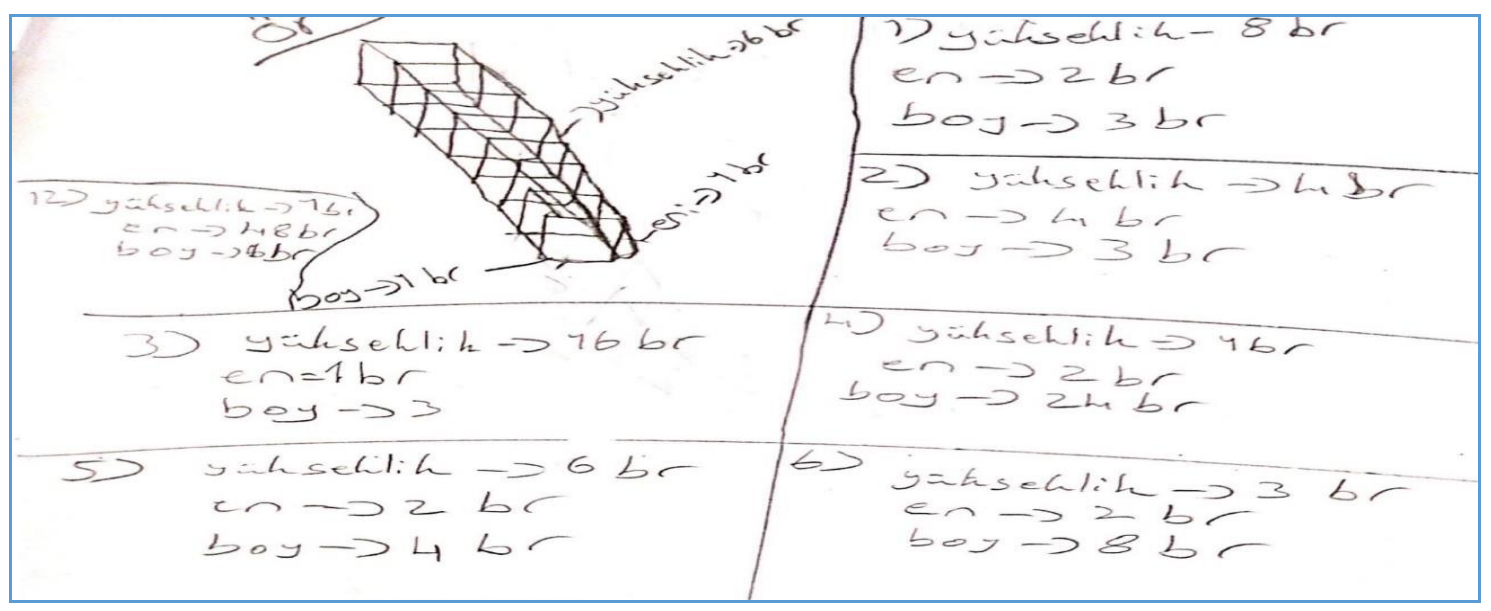

As seen in Figure 8, student S20 wrote the width, length and height of the rectangular prism models that can be created with 48 units of cubes. However, since rectangular prism models that can be written on the student's solution sheet are missing, it cannot be said that the student has reached a complete mathematical solution. In addition, in this activity, some students used visual figures while writing rectangular prism models, while the student S20 wrote the values that only width, length and height can take. The student, who could not interpret the solution, was able to verify his solution by reaching the relation that the product of width, length and height is equal to the volume of the rectangle.

Findings regarding the Fourth Mathematical Modeling Activity. In the "Cinema Hall" activity, which is the fourth activity of the research, the students were asked to find out how many square meters of space for a 300-person cinema hall in accordance with the standards. Information such as how many seats will be in horizontal and vertical rows, how wide the seat width or door gap should be, are left to the students' preference. Students were asked to obtain this information required for the solution of the problem by assuming. In this activity, which was also implemented in groups, the scores of the students according to different levels of reading comprehension skills are given in the Figure below:

Figure 9

Students' Modeling Efficiency Score Average in the $4^{\text {th }}$ Activity according to Their Reading Comprehension Levels

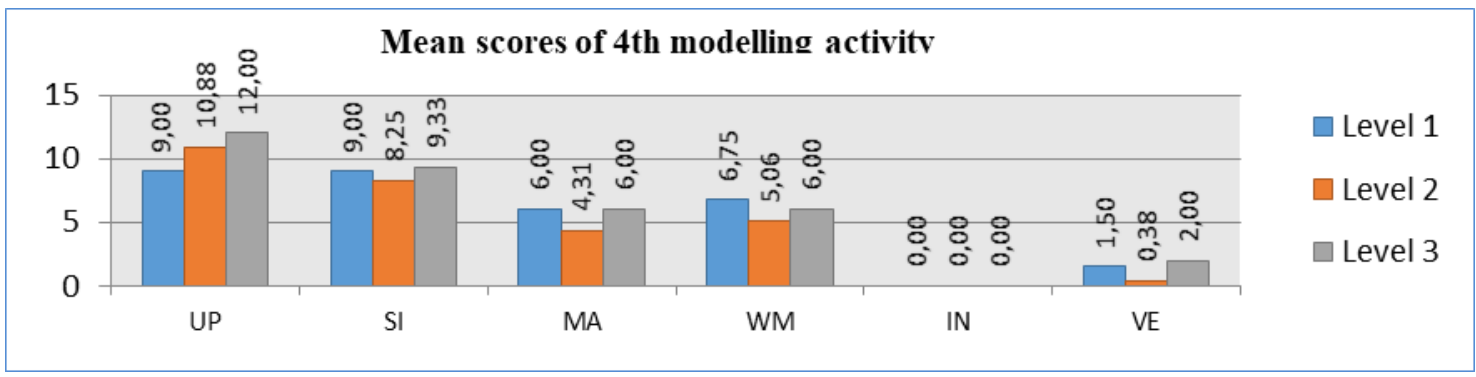


As seen in the Figure above, the students with the highest average in the steps of "understanding the problem", "simplification" and "verification" were again at the level 3. The students who could not succeed in the "interpretation" level were also weak in the "verification" level in this activity. The interesting situation that emerged in this activity is that the students who have little interest in the lesson and who are at the level 1 in terms of reading comprehension skills have high averages especially in this activity. Moreover, it is seen that these students are more successful in mathematical modeling skills, except for "understanding the problem" and "interpretation" skills, compared to students at level 2 in terms of reading comprehension skills. In this activity, in terms of reading comprehension skill, the modeling step in which level 2 and 3 students achieved the most success in general was the "understanding the problem" step, and the step where level 1 students achieved the most success was the "simplification" step. In Figure 10, a section is given from the activity sheet of student S16 at level 1:

Figure 10

Activity Sheet of S16 Student

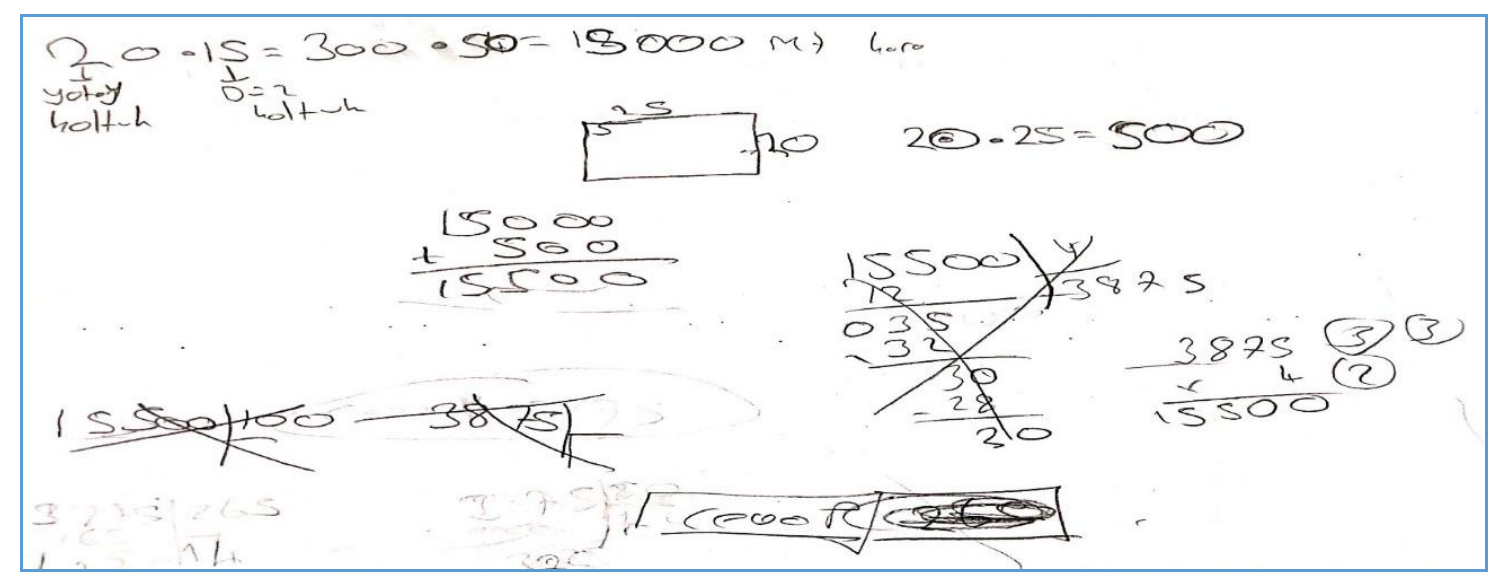

In this activity, the student $\mathrm{S} 16$ made a reasonable assumption about the number of seats that should be in a horizontal and vertical row, but it was seen that student did not follow a logical path in solving. In this case, it can be said that the student made missing assumptions and formed an incomplete model. Considering the student diaries, it was seen that the students generally stated that they had difficulty in the activity, and the reason for this was that they had trouble in forming assumptions.

Findings regarding the Fifth Mathematical Modeling Activity. In the "Electricity Saving" activity, which is the fifth activity of the process, students were asked to find the annual amount of electricity savings if each family in the country saves 1 hour from the lights of the rooms in their home. The population of the country and the amount of energy consumed by a light bulb per hour were given to students as additional information, and information such as the number of households in the country and the number of rooms in each household was left to the student's preference and they were asked to make assumptions about this. The Figure with the mean scores of mathematical modeling competence according to the reading comprehension skill levels of the students is given below: 
Figure 11

Students' Modeling Efficiency Score Average in the $5^{\text {th }}$ Activity according to Their Reading Comprehension Levels

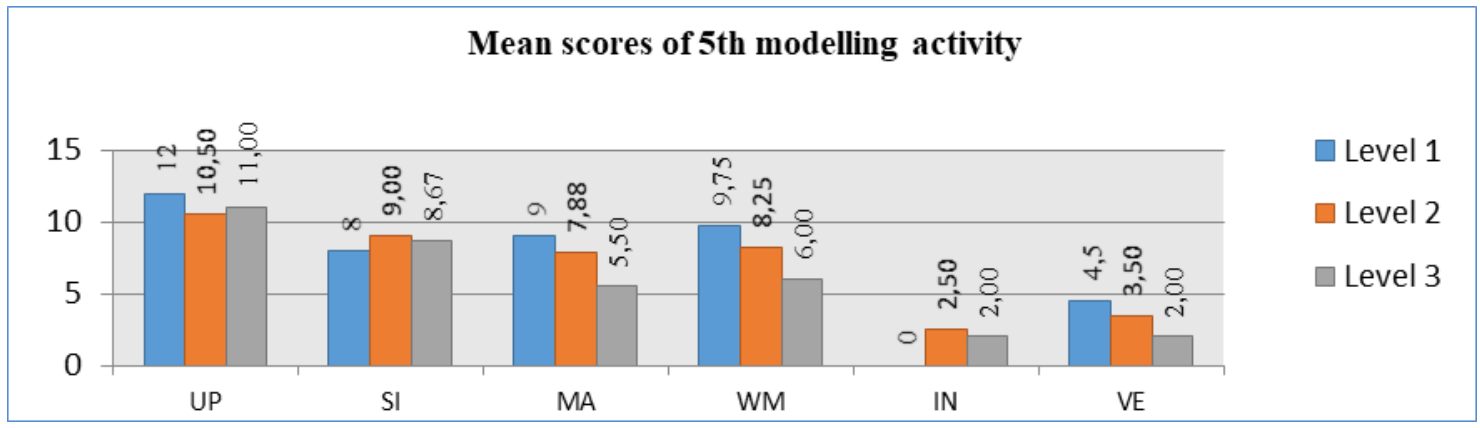

As seen in Figure 11, students at the level 1 in terms of reading comprehension skill, except for "simplification" and "interpretation" skills, showed higher success in other mathematical modeling skills compared to the students at the level 2 and 3 in this activity. In addition, from the student diaries at the levels 2 and 3 regarding this activity, it was seen that these students stated that they had difficulty in forming assumptions as in the previous activity and therefore they did not like the activity.

The fact that the mean score of all students in the "understanding the problem" level is higher than the mean score in other steps in this activity indicates that they understand the problem but have difficulty in reaching a solution. In Figure 12, the activity sheet of the student S25 who is at the level 2 in terms of reading comprehension is given:

Figure 12

Activity Sheet of Student S25

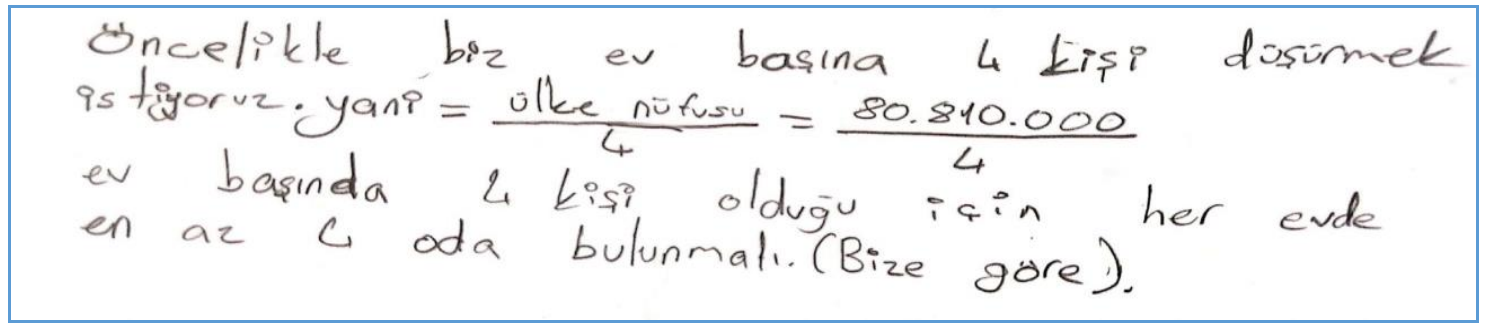

As can be seen in the Figure 12, the student made a reasonable assumption for the solution by determining the average number of people in the family as 4 and the total number of rooms in a family of 4 people as 4 (The house, bathroom, entrance, etc. locations are not taken into account).

Findings regarding the Sixth Mathematical Modeling Activity. In the "Oil Spill" activity, the sixth activity of the implementation process, students were asked to find the area where the oil spilled as a result of the puncture of an oil tanker spread to the sea. Although the students who could not compare the area where the oil spreads to the shapes, they are familiar with, such as square or rectangle, had difficulty at the beginning of the activity, they tried to find the area of the shape by trying to compare it to a square or rectangle. The mean scores obtained by students from each step of 
mathematical modeling according to their reading comprehension skill levels are given in the Figure below:

Figure 13

Students' Modeling Efficiency Score Average in the $6^{\text {th }}$ Activity according to Their Reading Comprehension Levels

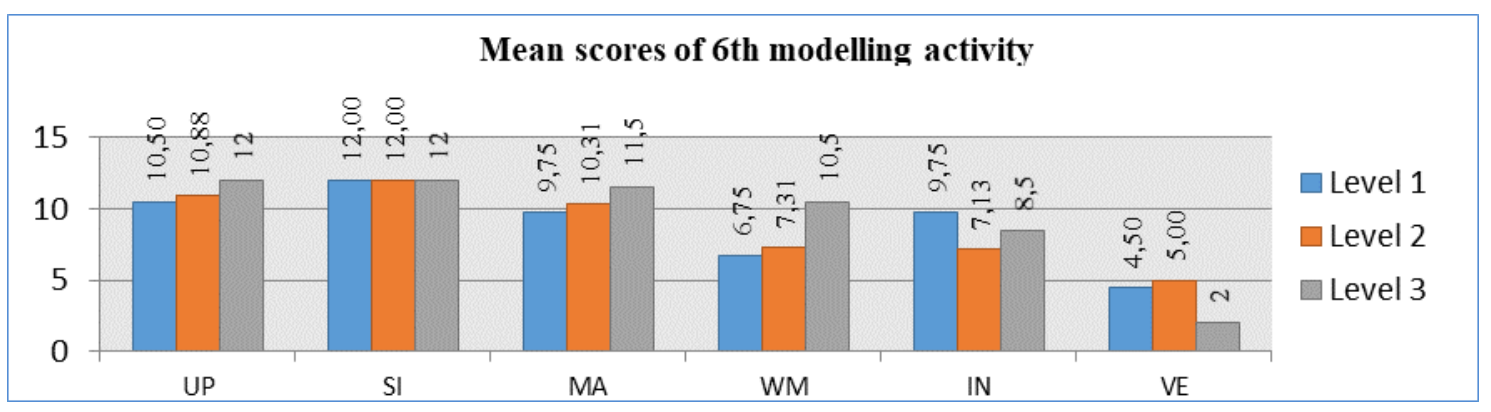

As seen in the Figure 13, the students with the highest average in the levels of "understanding the problem", "mathematization" and "mathematical study" were level 3 students, while the level 1 students at the "interpretation" step and the level 2 students at the "verification" step had a higher mean score than the other students. Moreover, in terms of "interpretation" and "verification" efficacies, level 1 students were more successful than level 3 students. The solution sheet of the activity of student S13 who is at the level 2 in terms of reading comprehension is given in Figure 14:

Figure 14

Activity Sheet of Student S13

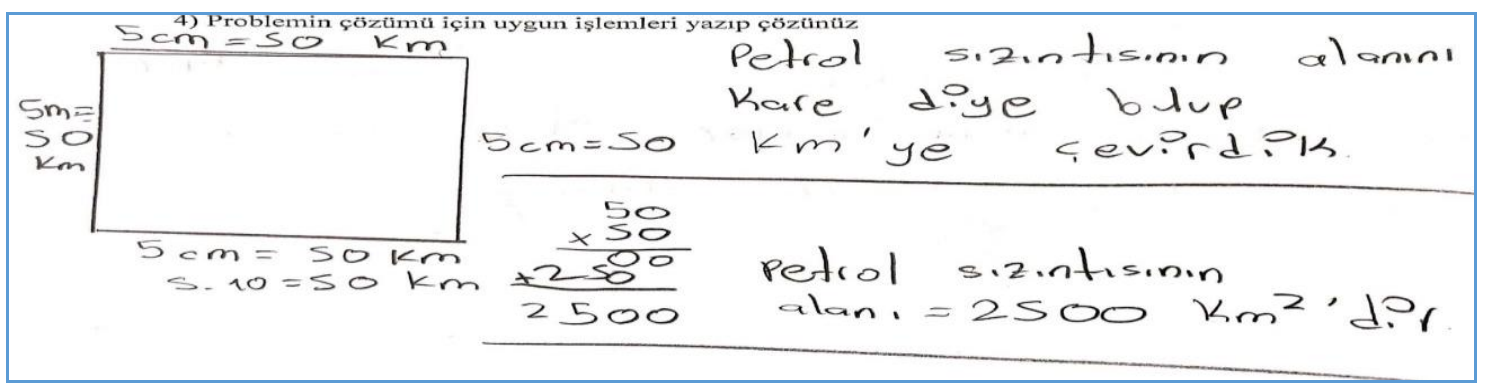

As seen in the Figure 14, the student thought of the shape as a square and calculated its area by measuring the length of one side with a ruler. The student's assumption that the shape is square and the measurements made with a ruler ensured that the student's estimated result was close to the truth.

Findings regarding the Seventh Mathematical Modeling Activity. In the seventh activity of the process, the students were asked to estimate the total amount of precipitation in 2019 by giving the annual rainfall figure between 1981-2016 in their province. In this individually implemented activity, the students did not experience any difficulties in understanding the problem step, but had difficulties in creating a mathematical model. The mean scores obtained by the students from each step of mathematical modeling according to their reading comprehension skill levels are given in the Figure below: 
Figure 15

Students' Modeling Efficiency Score Average in the $7^{\text {th }}$ Activity according to Their Reading Comprehension Levels

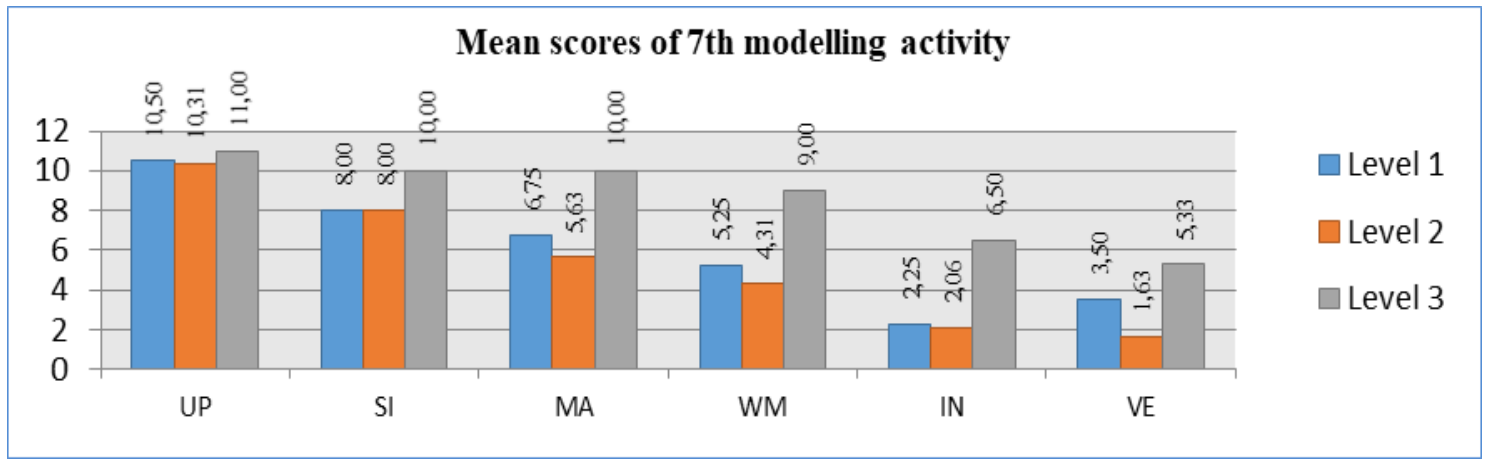

Looking at the Figure 15, it is seen that the modeling step in which all of the students are most successful in general is the "understanding the problem" step, and the level 3 students have the highest average in every step of mathematical modeling. In addition, this activity, which is applied individually to the students, reveals how the development of mathematical modeling competencies of the students progressed compared to the first activity.

Below, sample opinions taken from activity papers belonging to three level student groups are presented to interpret the problem:

Figure 16

A Section from the Activity Sheet for "Interpreting the Problem" of the Student $S 17$

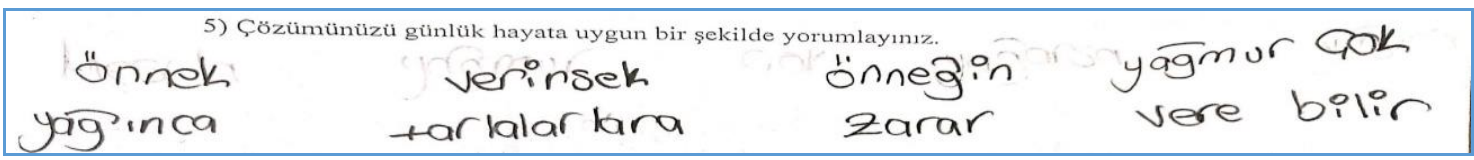

Student S17, who is at the level 1 in terms of reading comprehension skill, answered the instruction question corresponding to the interpretation step of mathematical modeling as above. The comment made by the student as "For example, when it rains a lot, it can damage the fields" is realistic and logical as well as short and insufficient. In Figure 17, the comment of the student S25 at the level 2 of the same activity is seen:

Figure 17

A Section from the Activity Sheet for "Interpreting" the Problem of Student S25

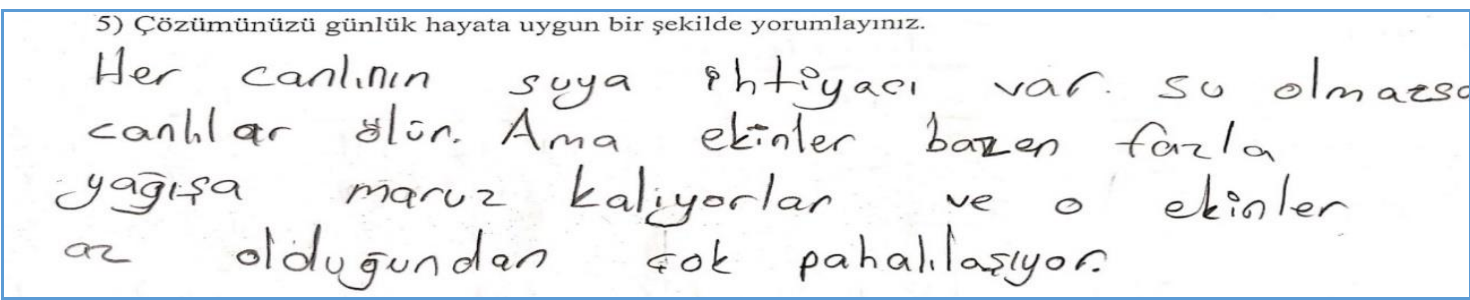


As can be seen in the Figure 17, the student said, "Every living thing needs water. Without water, living beings would die. But crops are sometimes exposed to high rainfall and they get very expensive because they are less", is more revealing than the previous student's comment. In addition, this student justified his interpretation different from the previous student. The opinion of the student S19, who is at the level 3 in terms of reading comprehension skill, taken from the activity sheet for "interpreting" the problem is presented below.

Figure 18

A section of the $S 19$ student's activity sheet for "interpreting the problem"

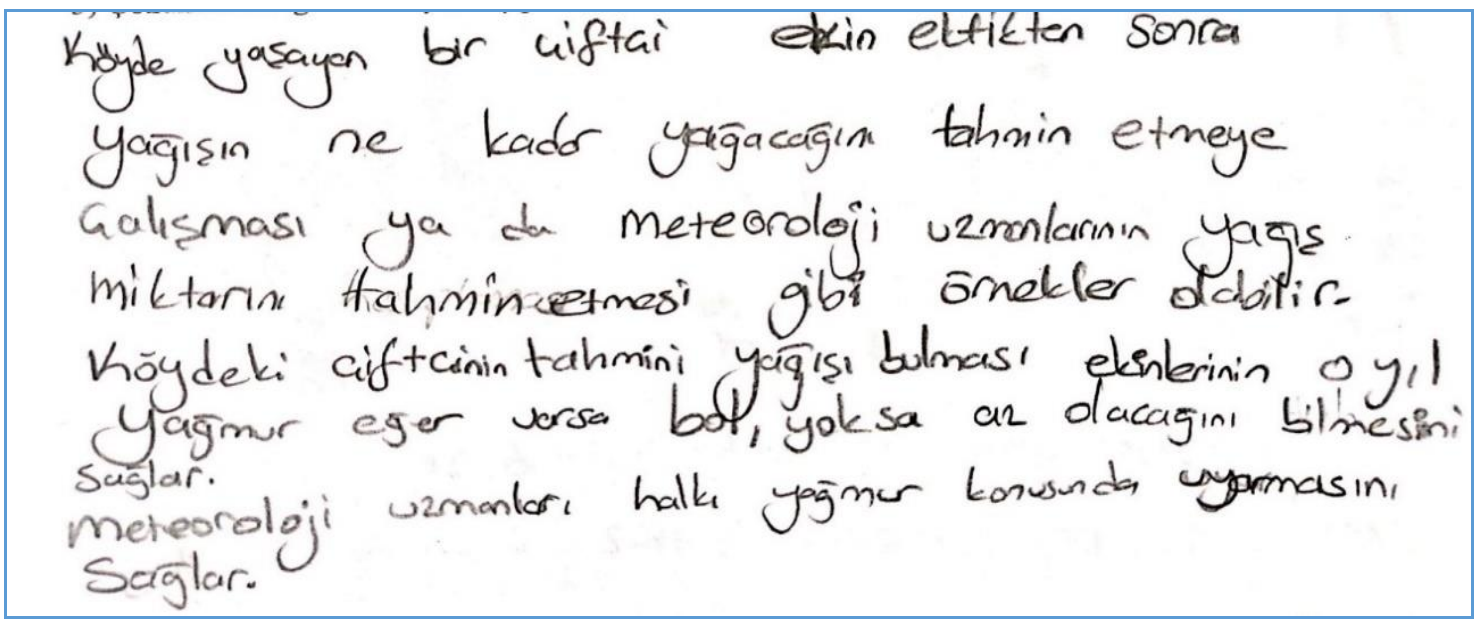

In the Figure above, the interpretation of the solution that student S19 at the level 3 has made is given. The student stated through saying "There may be examples such as a farmer living in a village trying to predict how much rain will fall after planting a crop or meteorologists predicting the amount of rainfall. Finding the estimated rainfall allows the farmer in the village to predict that their crops will be abundant if there is rain that year, or less. It enables meteorologists to warn the public about rain" where the solution he obtained could be used in daily life and what kind of benefits it provided. The given examples support the view that students with advanced reading comprehension skills are generally more successful in mathematical modeling activities.

\section{Change of Mathematical Modeling Sub-Competences According to} Reading Comprehension Levels

The findings on how each mathematical modeling sub-competence of students at different levels in terms of reading comprehension skills changed during the application process are discussed below.

The Status of the Students in terms of Understanding the Problem Competence. The change in the students' competence to understand the problem during the application process is presented in the column chart below. 
Figure 19

Change in Understanding the Problem Competencies according to Students' Reading Comprehension Level

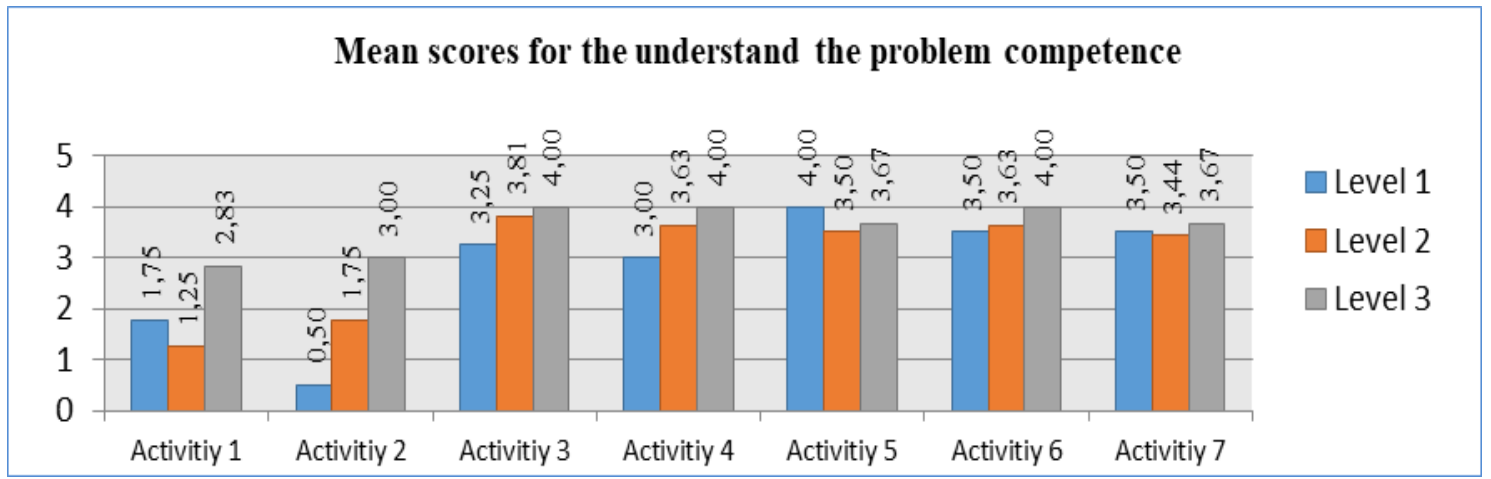

As seen in the Figure 19, the scores of the students' level of understanding the problem in the last five activities increased significantly compared to the first two activities. However, although the last activity was applied individually, the students' scores of understanding the problem were roughly similar to the previous activity scores. In addition, in all activities except the activity 5, level 3 students had a higher mean score in the level of understanding the problem than the other students

The Situation of the Students in terms of Simplification Competence. The change in the simplification competencies of the students during the application process is presented in the column chart below.

Figure 20

Change in Simplification Competencies according to Students' Reading Comprehension Level

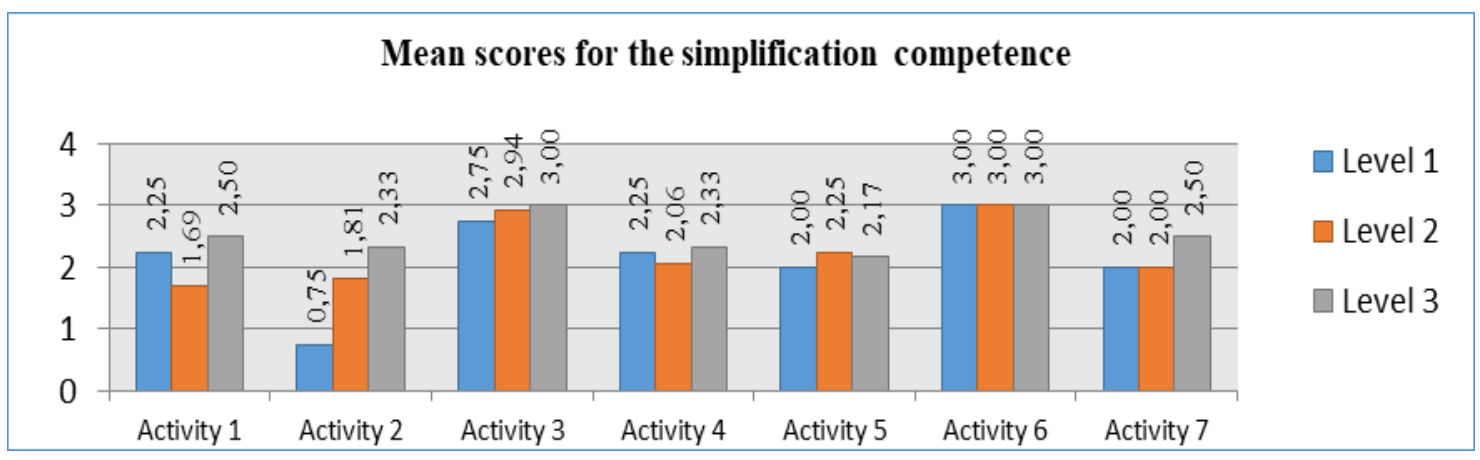

Together with the level of understanding the problem, this step was the modeling step in which the students achieved the most success compared to the other steps. On the other hand, it is observed that there is no regular development from the first activity to the last activity. It is seen that the students got higher scores in the activities 3 and 6 in the simplification step. In parallel with this, it was seen that the students gave more positive opinions about these activities in the process. When looking at the Figure 20, it can be seen that level 3 students generally have a higher mean score in the simplification step than other students. 
The Status of Students in terms of Mathematicization Competence. The change in the simplification competencies of the students during the implementation process is presented in the Figure below.

Figure 21

Change in Mathematicization Competencies according to Students' Reading Comprehension Level

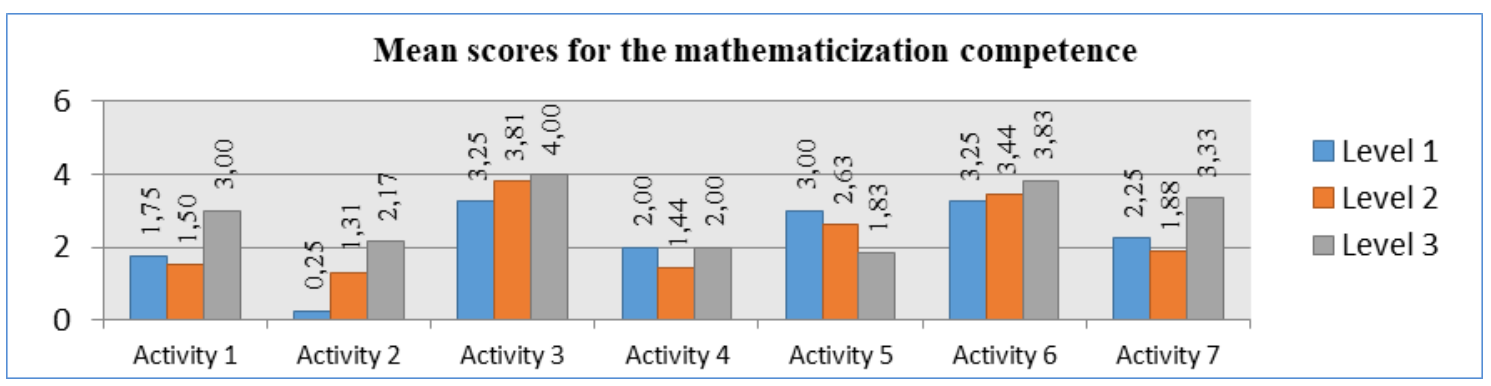

It is observed that the development of students in the mathematicalization step from the first activity to the last activity does not follow a regular course. In this modeling step, it is seen that the activities with the highest scores are the activities 3 and 6 as in the previous step. Looking at the Figure, it can be seen that the level 3 students generally have a higher mean score than the other students in the mathematization step.

The Status of Students in terms of Mathematical Work Competence. The change in the mathematical study competencies of the students during the implementation process is presented in the column chart below.

Figure 22

Change in Mathematical Work Competencies according to Students' Reading Comprehension Level

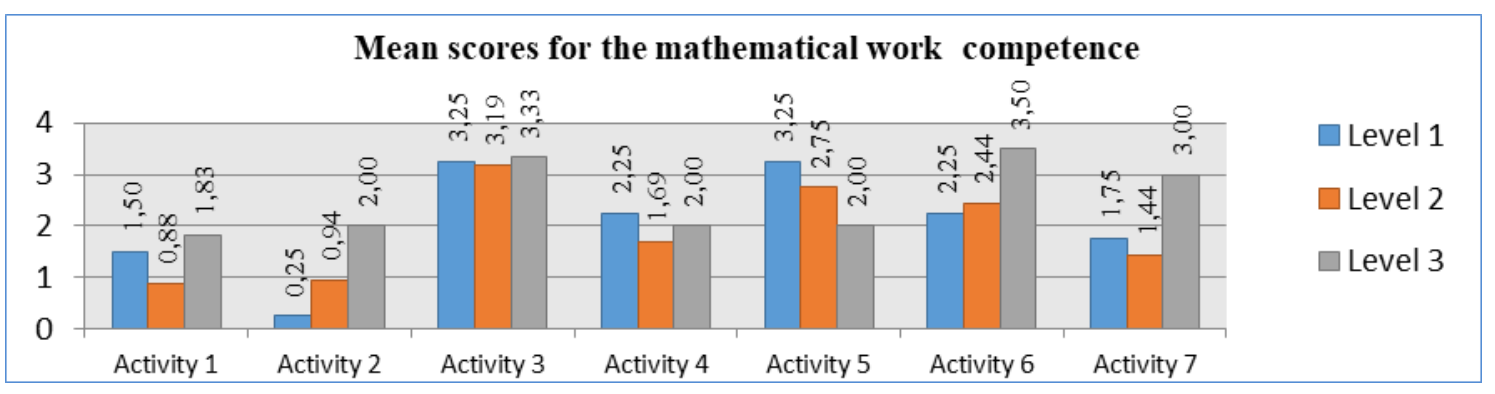

When the Figure 22 is analyzed, it is seen that the achievement scores of all three levels of student groups have increased compared to the first two activities. In all activities except activities 4 and 5, it can be seen that level 3 students have higher mean score success than other students.

Status of Students in terms of Interpretation Competence. The change in the interpretation competencies of the students during the implementation process is presented in the column chart below. 
Figure 23

Change in Interpretation Competencies according to Students' Reading Comprehension Level

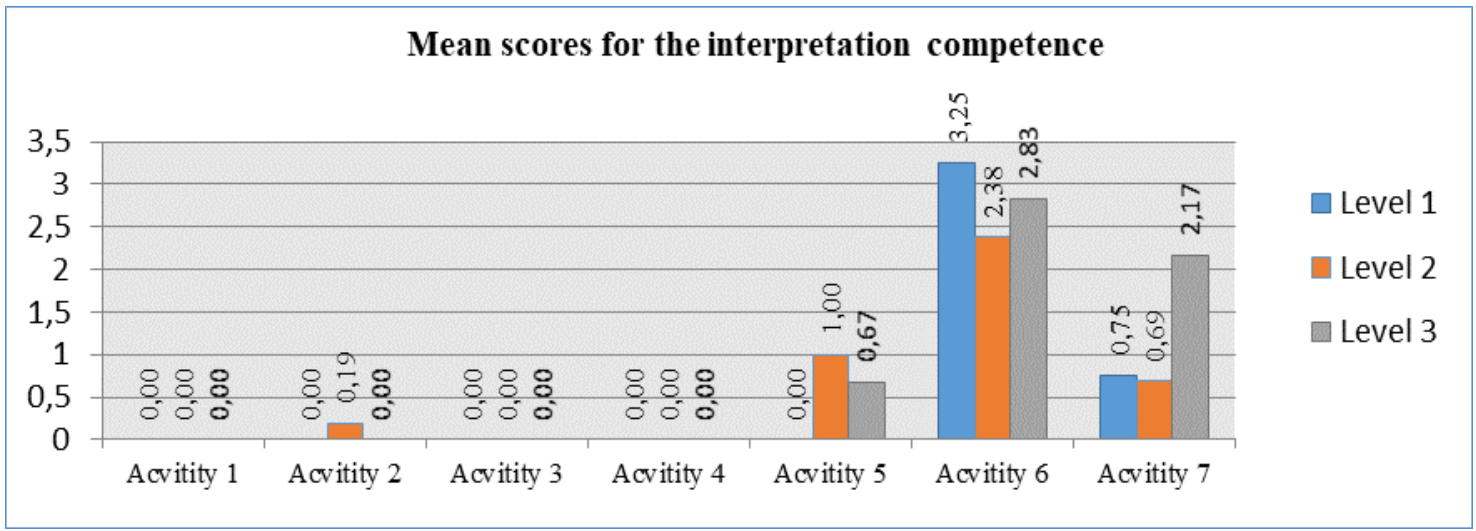

As can be seen in the Figure, there has been an increase in the interpretation step mean score of the students in the last three activities. As a matter of fact, it has been observed that most of the students devote the entire time remaining after reaching the solution stage in a given modeling problem to completing and checking the solution.

Some students stated that they forgot to interpret after completing the solution in the process. As a matter of fact, the students did not experience time problems in the activities carried out by the group in the process, and they needed more time in individual activities. In the last individually applied activity, some students stated that they allocated the entire time to the solution and to check the solution and that they could not find time to interpret.

Status of Students in terms of Verification Competence. The change in the verification competencies of the students during the application process is presented in the column chart below.

Figure 24

Change in Verification Competencies according to Students' Reading Comprehension Level

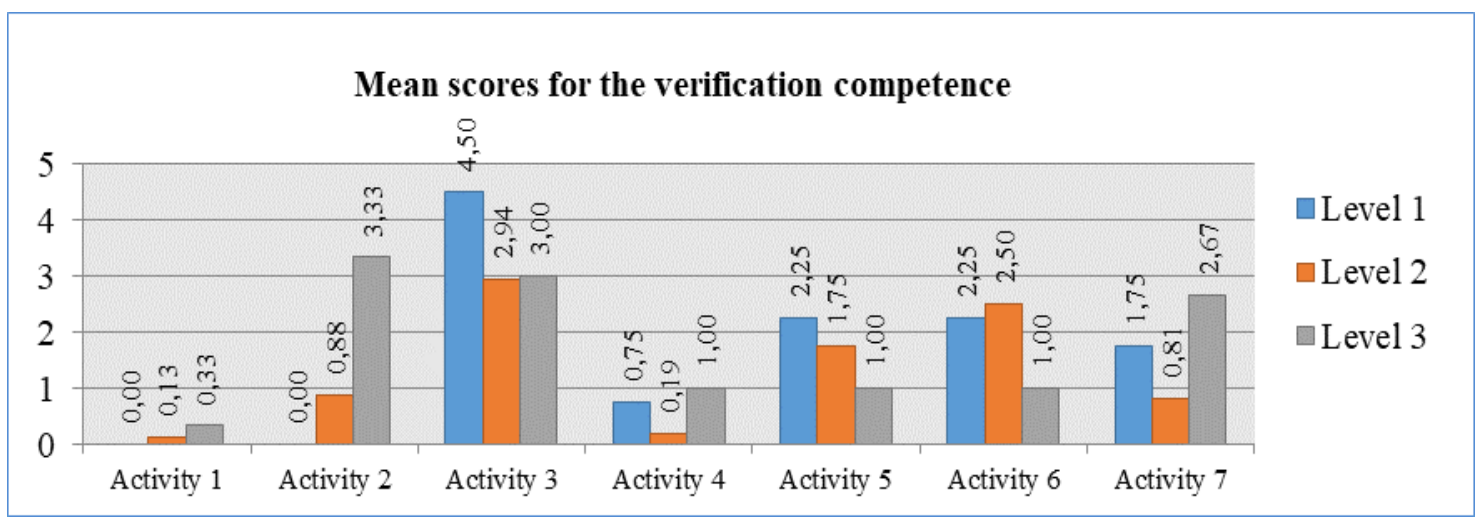

When the Figure is examined, it is seen that the activity with the highest mean score in the verification step is the activity 3, in other words the "Unit Cubes" activity. On the other hand, when looking at the last four activities, it can be seen that the total 
verification scores of the students increased in general. As a matter of fact, it is seen that the students at the level 3 in the verification step in the activities 1,2 and 7 implemented individually have higher scores.

\section{Discussion and Conclusion}

In this study, the effect of MAIP on mathematical modeling competencies of students with different levels of reading comprehension skills was examined. The first sub-problem of the study examined the relationship between students' reading comprehension skills and their mathematical modeling competencies. As a result of the analysis, it was observed that there was a positive, low level relation between the scores of reading comprehension skills and mathematical modeling competence before the process, and a positive, high-level relationship between the scores of reading comprehension skills and mathematical modeling competence after the process. In addition, reading comprehension skill scores were associated with each step of mathematical modeling and it was seen that this relationship was significant for each step. This finding shows that the mathematical modeling competencies of students with advanced reading comprehension skills are also more advanced than other students. The reason why this relationship is higher in post-test scores compared to pre-test scores can be explained by the fact that students who encounter mathematical modeling problems for the first time may follow similar ways in solving the problems; therefore, the levels of modeling competence of students at different levels in terms of reading comprehension skills have not yet differed from each other. Ural and Ülper (2013) evaluated the reading comprehension skill and mathematical modeling competence of prospective teachers through the "understanding the problem" step in their studies. They stated that the prospective teachers who were successful in the "understanding the problem" step, one of the mathematical modeling steps, understood what they read well. In addition, Biccard (2010) suggested that the failure of students with poor mathematical skills to complete some mathematical modeling tasks is related to their reading level and reading comprehension. However, it was stated that this link was beyond the scope of Biccard's work and should be considered as a complete study on its own. Plath and Leiss (2018) also investigated the effect of linguistic complexity on solving mathematical modeling tasks in their studies with middle school students. They stated that reading comprehension greatly influenced the creation of an appropriate case model and the successful solving of a mathematical modeling task. Krawitz et al. (2017), on the other hand, concluded that, contrary to expectations, reading comprehension does not have much effect on mathematical modeling performance and stated that the reason for this may be related to the fact that the modeling problems they present to students are challenging even for students with a good understanding. The results obtained from the studies in general support the view that there is a relationship between mathematical modeling and reading comprehension skills.

In the second sub-problem of the study, the development of mathematical modeling competencies of the students was evaluated according to their reading comprehension level. The mathematical modeling competencies of the students, who were divided into three levels according to their reading comprehension test scores, were analyzed from the first activity to the last activity and comparisons were made. The first two activities were applied individually and as expected, the students at the 3rd 
level were more successful. However, students at the 1st level in the first activity showed more success than the 2 nd level students. This can be because students at the 2nd level are mostly girls and are less familiar with football than boys (All of the students in the 1st level are boys.). The third activity was held in groups at the intensive request of the students, and students generally progressed in all sub-levels except the interpretation step. In this activity, 3rd level students achieved more success in the first four steps of mathematical modeling. The fourth, fifth and sixth activities were also carried out in groups, as the students achieved success in this group activity. In the fourth activity, 3rd level students were generally more successful, but in this activity they were weak in the verification step compared to the previous activity. The fact that this activity requires more complex operations compared to the previous activity can be shown as a reason for this situation. In addition, in this activity, it was observed that students also had difficulties in making assumptions. When it comes to the fifth activity, it is seen that there is an increase in students' success in the interpretation step. In this activity, it is striking that 1st level students are more successful in the UP, MA, WM and VE levels than other students. It can be said that working in groups has a significant effect on the success of 1 st level students. The fact that 3rd level students are less successful may be due to the fact that this activity includes crowded operations. As a matter of fact, it was understood from the students' opinions taken at the end of the activity that the students did not like the activities with crowded operations. 3rd level students were generally more successful in the sixth activity. In addition, it is seen that there is a significant increase in the interpretation step in this activity. The last activity was applied individually in order to observe the progress of the students more clearly. In this activity, it was observed that 3rd level students were much more successful than other students, while 1st and 2nd level students' achievement levels were almost close to each other. In this activity, it is also seen that there is a significant improvement in the interpretation step of the students.

Another point that should be emphasized in the study is that students are more successful in the activities they like. When students' favorite activities are considered, it is seen that there are activities that do not involve complex operations, such as "The Mystery of Unit Cubes" and "Oil Spill". They disliked activities such as "Cinema Hall" and "Electricity Saving" that required much mathematical processing. This finding provides important data on how the activities should be in order to develop a positive attitude towards students' mathematical modeling activities.

If the development of mathematical modeling sub-competencies of students is examined in the process, it will be seen that 3rd level students are more successful than other students in general. This finding shows that reading comprehension skill affects not only the level of understanding the problem, but also the success in other sub-levels of mathematical modeling. Özsoy et al. (2015), also found in their study that students' problem-solving skills vary according to different reading levels. On the other hand, another remarkable finding in the study is that the steps in which students show the highest success are "understanding the problem" and "simplification" steps, and the steps they have the lowest success level are "interpretation" and "verification" steps. Tekin-Dede and Yilmaz (2015) also observed in their study with 6th grade students that students experienced the most difficulties in the interpretation and verification stages. Yurtsever (2018) also reached a similar result by observing a decrease in the modeling 
competence of students from understanding the problem to the verification step in her study. Similar findings can be found when the international literature is examined (Blum, 2011; Ji, 2012; Maaß, 2006). One of the reasons for the low level of success in the interpretation step is that students finish the solution after finding the answer to the problem in classical math questions, therefore they are not used to interpret the answer. In addition, many students stated that they forgot to interpret the solution after the activity was ended. During the process, some students stated that they did not know how to associate with daily life, comment, or express the interpretation after they obtained the solution. It was observed that students also had difficulties making assumptions, again due to the absence of classical mathematical problems. This situation may be due to the inability of students to develop their expression and prediction skills due to the lack of reading habits, and also to the difficulties they experience in associating the solution of the problem with daily life due to the limited socio-cultural environment in rural areas.

\section{Implementations}

In the light of the findings obtained from this study, the following implementations are made:

Increasing the use of mathematical modeling activities in lessons and providing teachers in-service training on mathematical modeling may be beneficial in terms of effective teaching and permanent learning. In addition, due to the absence of a control group and the limited number of students in this study, it is thought that more experimental studies, especially with a control group, are needed to examine the relationship between mathematical modeling competencies and reading comprehension skills. In this respect, it is recommended to conduct research at different grade levels related to the subject.

Considering that students like activities with less complex operations more, students who are new to mathematical modeling can be recommended to apply activities that will improve their skills, such as understanding the problem, reasoning, making assumptions, and making comments, instead of activities involving complex operations. In fact, activities can be designed specifically to develop each mathematical modeling sub-competency. For example; As seen in this study, considering that students failed especially in interpretation and verification stages while solving mathematical modeling problems, it is recommended that teachers apply mathematical modeling activities based on interpretation in their lessons. In order to overcome the deficiencies in interpretation skills of the students, cooperation can be made, especially with Turkish course teachers. In addition, considering that students are more successful in activities in which they work in groups, it is recommended to implement the activities in groups.

Considering the relationship between mathematical modeling competencies and students' reading comprehension skills, it can be said that the failure of some students in mathematical modeling processes is due to their difficulties in reading comprehension. In this regard, it is recommended to take more effective steps to improve students' reading comprehension skills. It should not be forgotten that reading comprehension is the basis for understanding and solving a problem, and it should be ensured that teaching practices that increase the level of reading comprehension are given to students from primary school years. 
It is recommended to prepare activities that can be given as homework to students who are at a low level in terms of reading comprehension skills to benefit from modeling activities. Care should be taken that these activities are aimed at understanding the problem and do not contain crowded operations that will distract the student from the activity and the lesson. In addition, since the problems in the existing textbooks do not appeal to modeling too much, it is recommended to change the textbooks to create textbooks that include mathematical modeling activities suitable for different levels and to create teacher guide books that contain instructions on how to apply the activities.

\section{Statement of Responsibility}

Yasemin Alkan; research design, analysis, methodology, data collection, resources, discussion, conclusion, writing-original draft, writing - review \& editing. Mehmet Aydın; methodology, writing -original draft, writing - review \& editing, resources, discussion, conclusion, supervision.

\section{Conflicts of Interest}

There are no conflicts of interest in this study. 


\section{References}

Albayrak, E., \& Çiltaş, A. (2017). Türkiye'de matematik eğitimi alanında yayınlanan matematiksel model ve modelleme araştırmalarının betimsel içerik analizi. Uluslararası Türk Eğitim Bilimleri Dergisi, 9, 258-283.

Baykul, Y. (1995). Matematik öğretimi. Ankara: Anı Yayıncılık.

Biccard, P. (2010). An investigation into the development of mathematical modelling competencies of grade 7 learners [Unpublished master's thesis]. Stellenbosh University.

Blomhøj, M. (2009). Different perspectives in research on the teaching and learning mathematical modeling. Categorising the TSG21 papers. In Blomhøj M. \& S. Carreira (Eds.), Mathematical applications and modeling in the teaching and learning of mathematics (pp.1-17). Roskilde: Roskilde University.

Bloom, B. S. (1995). Insan nitelikleri ve okulda öğrenme (Çev: D. A. Özçelik). İstanbul: Milli Eğitim Bakanlığı Yayınları.

Blum, W. (2011). Can modelling be taught and learnt? Some answers from empirical research. In G. Kaiser, W. Blum, R. Borromeo Ferri, \& G. Stillman (Eds.), Trends in teaching and learning of mathematical modelling. International perspectives on the teaching and learning of mathematical modelling (pp. 15-30). New York: Springer.

Blum, W. (2015). Quality teaching of mathematical modelling: What do we know, what can we do? In S. J. Cho (Ed.), The Proceedings of the 12th International Congress on Mathematical Education: Intellectual and attitudinal challenges (pp. 73-96). New York, NY: Springer.

Blum, W., \& Borromeo Ferri, R. (2009). Mathematical modelling: can it be taught and learnt? Journal of Mathematical Modelling and Application, 1(1), 45-58.

Blum, W., \& Leiß, D. (2007). How do students' and teachers deal with modelling problems? In C. Haines, P. Galbraith, W. Blum \& S. Khan (Eds.), Mathematical modelling: Education, engineering and economics (pp. 222-231). Chichester: Horwood Publishing.

Blum, W., \& Niss, M. (1991). Applied mathematical problem solving, modelling, applications, and links to other subjects-State, trends and issues in mathematics instruction. Educational studies in mathematics, 22(1), 37-68.

Borromeo Ferri, R. (2006). Theoretical and empirical differentiations of phases in the modelling process. The International Journal on Mathematics Education, 38(2), 86-95.

Brown, J. P., \& Stillman, G. A. (2017). Developing the roots of modelling conceptions: 'Mathematical modelling is the life of the world'. International Journal of Mathematical Education in Science and Technology, 48(3), 353-373. http://dx.doi.org/10.1080/0020739X.2016.1245875

Çiftçi, C., Sezgin Memnun, D., \& Aydın, B. (2018). Ortaokul öğrencilerinin okuma becerileri ile matematik problemlerini çözme başarıları arasındaki ilişkiler. The Journal of Academic Social Science Studies, 73, 531-544.

Çiltaş, A., \& Işık, A. (2012). Matematiksel modelleme yönteminin akademik başarıya etkisi. Çă̆daş Ĕ̈itim Dergisi Akademik, 1(2), 57-67. 
Creswell, J. W. (2016). Araştırma deseni: Nitel, nicel ve karma yöntem yaklaşımları. (S. B. Demir, Çev.). Ankara: Eğiten Kitap.

Creswell, J. W., \& Plano Clark, V. L. (2018). Karma yöntem araştırmaları: Tasarımı ve yürütülmesi. (Y. Dede ve S. B. Demir, Çev. Ed.). Ankara: Anı Yayıncılık.

Doruk, B. K. (2010). Matematiği günlük yaşama transfer etmede matematiksel modellemenin etkisi [Doktora tezi]. Hacettepe Üniversitesi.

Erbaş, A. K., Kertil, M., Çetinkaya, B., Çakıroğlu, E., Alacacı, C., \& Baş, S. (2014). Matematik eğitiminde matematiksel modelleme: Temel kavramlar ve farklı yaklaşımlar. Kuram ve Uygulamada Eğitim Bilimleri, 14(4), 1-21. http://dx.doi.org/10.12738/estp.2014.4.2039

Erdem, E. (2016). Matematiksel muhakeme ile okuduğunu anlama arasındaki ilişki: 8. sınıf örneği. Adlyaman Üniversitesi Necatibey Eğitim Fakültesi Elektronik Fen ve Matematik Ĕ̈itimi Dergisi (EFMED), 10(1), 393-414.

Gökkurt, B., Örnek, T., Hayat, F., \& Soylu, Y. (2015). Öğrencilerin problem çözme ve problem kurma becerilerinin değerlendirilmesi. Bartın Üniversitesi Ĕgitim Fakültesi Dergisi, 4(2), 751-774. https://doi.org/10.14686/buefad.v4i2.5000145637

Hıdıroğlu, Ç. N. (2015). Teknoloji destekli ortamda matematiksel modelleme problemlerinin çözüm süreçlerinin analizi: Bilişsel ve üst bilişsel yapılar üzerine bir açıklama [Doktora Tezi]. Dokuz Eylül Üniversitesi.

Hinton, P. R., Brownlow, C., McMurray, I., \& Cozens, B. (2004). SPSS Explained. New York: Routledge Inc., New York.

Hitt, F., \& González-Martín, A. S. (2015). Covariation between variables in a modelling process: The ACODESA (collaborative learning, scientific debate and selfreflection) method. Educational studies in mathematics, 88(2), 201-219. https://doi.org/10.1007/s10649-014-9578-7

Ji, X. (2012). A quasi-experimental study of high school students' mathematics modelling competence. 12th International Congress on Mathematical Education, 8 July-15 July 2012, COEX, Seoul, Korea.

Kaçar, K. (2015). Hızlı okuma ĕgitiminin ortaokul 7. sınıf öğrencilerinin okuduğunu anlama becerilerine ve okumaya ilişkin tutumlarına etkisi [Yayımlanmamış yüksek lisans tezi] Furat Üniversitesi.

Kaiser, G. (2007). Modelling and modelling competencies in school. Mathematical modelling (ICTMA 12): Education, engineering and economics, 110-119.

Kaiser, G., \& Maaß, K. (2007). Modelling in lower secondary mathematics classroom problems and opportunities. In W. Blum, P. L. Galbraith, H. W. Henn, \& M. Niss (Eds.), Modelling and applications in mathematics education: The 14th ICMI Study (pp 99-108). Springer: New York.

Kaiser, G., \& Schwarz, B. (2006). Mathematical modelling as bridge between school and university. ZDM, 38(2), 196-208. https://doi.org/10.1007/BF02655889

Kaiser, G., \& Sriraman, B. (2006). A global survey of international perspectives on modelling in mathematics education. ZDM, 38(3), 302-310. https://doi.org/10.1007/BF02652813 
Kapur, J. N. (1982). The art of teaching the art of mathematical modelling. International Journal of Mathematical Education in Science and Technology, 13(2), 185-192. https://doi.org/10.1080/0020739820130210

Krawitz, J., Schukajlow, S., Chang, Y.-P., \& Yang, K.-L. (2017). Reading comprehension, enjoyment, and performance in solving modelling problems: How important is a deeper situation model? In B. Kaur, W. K. Ho, T. L. Toh, \& B. H. Choy (Eds.), Proc. 41th Conf. of the Int. Group for the Psychology of Mathematics Education (Vol. 3, pp. 97-104). Singapore: PME.

Lerkkanen, M. K., Rasku-Puttonen, H., Aunola, K., \& Nurmi, J. E. (2005). Mathematical performance predicts progress in reading comprehension among 7years old. European journal of psychology of education, 20(2), 121-137.

Lesh, R., \& Carmona, G. (2003). Piagetian conceptual systems and models for mathematizing everyday experiences. In R. Lesh \& H. Doerr (Eds.), Beyond constructivism: Models and modeling perspectives on mathematics problem solving, teaching, and learning (pp.71-96). New York: Routledge.

Lesh, R. A., \& Doerr, H. (2003). Foundations of model and modelling perspectives on mathematic teaching and learning. In R. A. Lesh \& H. Doerr (Eds.), Beyond constructivism: Amodels and modelling perspectives on mathematics teaching, learning and problem solving (pp. 3-33). Mahwah, NJ: Lawrance Erlbauum.

Maaß, K. (2006). What are Modelling Competencies? ZDM 38(2), 113-142. https://doi.org/10.1007/BF02655885

Ministry of National Education [MoNE]. (2018). Matematik dersi öğretim programı. Millî Eğitim Bakanlığı, Ankara.

O'Reilly, T., \& McNamara, D. S. (2007). The impact of science knowledge, reading skill, and reading strategy knowledge on more traditional "high-stakes" measures of high school students' science achievement. American Educational Research Journal, 44(1), 161-196. https://doi.org/10.3102\%2F0002831206298171

Özçelik, E. G. (2011). Okuduğunu anlama becerisinin başarıya etkisi [Yayımlanmamış Yüksek lisans tezi]. Hacettepe Üniversitesi.

Özdemir, A. Ş., \& Sertsöz, T. (2006). Okuduğunu anlama davranışının kazandırılmasının matematik başarısına etkisi. Marmara Üniversitesi Ĕ̈itim Bilimleri Dergisi, 23, 237-257.

Özsoy, G., Kuruyer, H. G., \& Çakıroğlu, A. (2015). Evaluation of students' mathematical problem-solving skills in relation to their reading levels. International Electronic Journal of Elementary Education, 8(1), 113-132.

Plath, J., \& Leiss, D. (2018). The impact of linguistic complexity on the solution of mathematical modelling tasks. ZDM, 50(1), 159-172.

Pollak, H. O. (1969). How can we teach applications of mathematics? Educational Studies in Mathematics, 2(2), 393-404.

Pollak, H. O. (1997). Solving problems in the real world (pp. 91-105). Why Nymbers Count: Quantitative Literacy for Tomorrow's America, New York: The College Board. 
Sandalc1, Y. (2013). Matematiksel modelleme ile cebir ögrretiminin öğrencilerin akademik başarılarına ve matematiği günlük yaşamla ilişkilendirmeye etkisi [Yüksek lisans tezi]. Recep Tayyip Erdoğan Üniversitesi.

Schmelzer, M., \& Schukajlow, S. (2017). Strategies for fostering students' reading comprehension while they solve modelling problems. In T. Dooley \& G. Gueudet (Hrsg), Proceedings of the Tenth Congress of the European Society for Research in Mathematics Education (CERME10, February 1-5, 2017) (S. 996-1003). Dublin, Ireland: DCU Institute of Education and ERME.

Schukajlow, S., Kolter, J., \& Blum, W. (2015). Scaffolding mathematical modelling with a solution plan. ZDM, 47(7), 1241-1254. https://doi.org/10.1007/s11858-0150707-2.

Şen-Zeytun, A. (2013). An investigation of prospective teachers' mathematical modeling processes and their views about factors affecting these processes [Unpublished doctoral dissertation]. Middle East Tecnical University.

Sert, A. (2010). İlköğretim altıncı sınıf öğrencilerinin okuduğunu anlama becerilerinin bazı değişkenler açısından incelenmesi [Yayımlanmamış yüksek lisans tezi]. Selçuk Üniversitesi.

Tekin-Dede, A. (2015). Matematik derslerinde öğrencilerin modelleme yeterliklerinin geliştirilmesi: Bir eylem araştırması [Yayımlanmamış doktora tezi]. Dokuz Eylül Üniversitesi.

Tekin-Dede, A. (2017). Modelleme yeterlikleri ile sınıf düzeyi ve matematik başarısı arasındaki ilişkinin incelenmesi. Illköğretim Online, 16(3), 1201-1219. http://dx.doi.org/10.17051/ilkonline.2017.330251

Tekin-Dede, A., \& Bukova-Güzel, E. (2014). Matematiksel modelleme yeterliklerini değerlendirmeye yönelik bir rubrik geliştirme çalışması. XI. Ulusal Fen Bilimleri ve Matematik Eğitimi Kongresi, Adana.

Tekin-Dede, A., \& Yılmaz, S. (2015). 6. Sınıf öğrencilerinin bilişsel modelleme yeterlikleri nasıl geliștirilebilir?. International Journal of New Trends in Arts, Sports \& ScienceEducation, 4(1), 49-63.

Ural, A., \& Ülper, H. (2013). İlköğretim matematik öğretmeni adaylarının matematiksel modelleme ile okuduğunu anlama becerileri arasındaki ilişkinin değerlendirilmesi. Kuramsal Eğitimbilim Dergisi, 6(2), 214-241.

Uzun, C. (2010). İlköğretim öğrencilerinin matematik dersi problem çözme başarılarının bazı demografik değişkenler ve okuduğunu anlama becerisi açısından incelenmesi [Yayımlanmamış yüksek lisans tezi]. Uşak Üniversitesi.

Vilenius-Tuohimaa, P. M., Aunola, K., \& Nurmi, J. E. (2008). The association between mathematical word problems and reading comprehension. Educational Psychology, 28(4), 409-426. https://doi.org/10.1080/01443410701708228

Walker, C. M., Zhang, B., \& Surber, J. (2008). Using a multidimensional differential item functioning framework to determine if reading ability affects student performance in mathematics. Applied Measurement in Education, 21(2), 162-181. https://doi.org/10.1080/08957340801926201

Yantır, N. (2011). İlköğretim 6. sinıf ögrencilerinin okuduğunu anlama becerilerinin incelenmesi [Yayımlanmamış yüksek lisans tezi]. Atatürk Üniversitesi. 
Y1ldırım, A., \& Şimşek, H. (2016). Sosyal bilimlerde nitel araştırma yöntemleri (10. baskı). Ankara: Seçkin Yayıncılık.

Yurtsever, A. (2018). 6. sinıf ögrencilerinin matematiksel modelleme yeterlikleri, matematik başarıları ve tutumları arasındaki ilişki [Yayımlanmamış yüksek lisans tezi]. Gazi Üniversitesi. 